\title{
Speelgoed van de slager: slachtdieren en kinderspel in de vroegmoderne Nederlandse literatuur*
}

\begin{abstract}
This article discusses cultural representations of slaughter animals from the early modern period, setting them against the post-modern approach to animals. The point of departure constitutes a contemporary story about a girl eating the heart of a deer, which she has shot. Then the author moves on to a discussion of the poem 'Kinder-spel' (1618/1625) by the seventeenth-century Dutch poet Jacob Cats and focuses on the socio-cultural notions of humans and animals which these two texts present. When discussing the poem, the author elaborates on the symbolic meaning of two situations where children play with animal body parts - a game of knucklebones and playing with an inflated bladder. The interpretation of Cats' text shows that the stereotypical social perceptions of slaughter animals which can be found in the early modern Dutch literature are in fact meant to offer a certain view on humans, by which their domination over the natural world and exploitation of animals is justified. The methodologies applied in this study involve the so-called 'activist ecocriticism' and the New Historicism, both being the reading methods, which emphasize the topicality of historical research. By placing Cats' texts in a broad context, it is shown that the motif of children playing with animal body parts refers to early modern polemics about such issues as the relationship between the human and animal, the tension between culture and nature, as well as children and upbringing models.
\end{abstract}

\section{Inleiding}

'Walgelijk', 'barbaars', 'psychopathisch' - met deze woorden reageerde men op een nieuwsbericht, dat midden augustus 2016 door verschillende nieuwssites wereldwijd werd gedeeld, over een achtjarig meisje uit Nieuw-Zeeland dat het rauwe

* Dit project is gefinancierd door het Nationaal Centrum voor Wetenschap (Narodowe Centrum Nauki), Polen beslissing nr: 2011/01/N/HS2/02103. Dank bij dezen aan prof. dr. Johan Koppenol (VU Amsterdam) voor zijn opmerkingen bij een eerste versie van dit artikel. Verder ben ik de redactie van Neerlandica Wratislaviensia en de recensenten van mijn bijdrage dankbaar voor hun kritische commentaar en veel waardevolle adviezen bij de uiteindelijke versie van deze tekst. 
hart van een neergeschoten hert had opgegeten. ${ }^{1}$ Alles begon met de foto's die de trotse vader van het meisje op de Facebookpagina van de New Zealand Woman Hunters had gezet. Zijn 'little pink ninja princess Chloe' - schrijft de vader - poseert hierop glimlachend met het dode lichaam van haar eerste geschoten hert. ${ }^{2}$ Op de volgende foto neemt zij een hap van 'its warm quivering heart'. Het bericht zorgde voor veel opschudding en kreeg duizenden reacties en commentaren en werd meer dan 20.000 keer gedeeld. De vader weerlegde de kritiek met het argument dat het hem alleen om het vlees ging. Bovendien legde hij de nadruk op het feit dat zijn dochter niet gedwongen was om het hart te eten: 'She wanted to do it when she saw a picture of her uncle biting the heart of his first deer'. Hij wees erop dat het opeten van je eerste geschoten dier een oud jagersritueel is. En hoewel de vader en de dochter het gebruik niet zo serieus nemen, had het meisje hierdoor bewezen dat 'she is a hunter now'.

De manier waarop mensen op de foto's reageren laat denkbeelden zien die met elkaar in botsing komen in het publieke debat over de relatie mens/natuur en over de opvoeding van kinderen. Voor sommigen is de hele situatie afschuwelijk en het gedrag van het meisje - sadistisch. Mensen vinden het moeilijk denkbaar dat het achtjarige kind zoiets uit zichzelf wilde uitvoeren. In hun ogen is de houding van de vader een teken van slecht, onverantwoordelijk ouderschap. Vertegenwoordigers van dierenwelzijn- en ecologieorganisaties wijzen er bovendien op dat een kind dat een geweer in haar of zijn handen krijgt en zelf een levend wezen doodt, in 'an alarming lack of compassion' wordt opgevoed. ${ }^{3}$ Dergelijke verhalen beschouwen eco-activisten als extreem gevaarlijk omdat ze de jacht als iets positiefs laten zien dat vermaak en plezier verschaft. Als gevolg hiervan kunnen ook anderen tot zulk gedrag aangezet worden. Er zijn echter ook mensen die de hele commotie niet begrijpen. In hun visie dienen de critici zich niet met een eeuwenoude traditie te bemoeien. Voor hen heeft de vader op die manier zijn zorg voor het overdragen van jagersrituelen aangetoond. Ze zien de tegenstanders als

${ }^{1}$ Zie bijvoorbeeld: 'She's a hunter now', Women in the World in association with the New York Times, 27 augustus 2016 [http://nytlive.nytimes.com/womenintheworld/2016/08/27/photosof-8-year-old-girl-eating-the-heart-of-her-first-kill-shock-users-on-facebook/; geraadpleegd op 29.08.2016]; Arno van Hauwermeiren, Vader laat dochtertje (8) rauw hart opeten van hert dat ze net heeft doodgeschoten, 24 augustus 2016 [http://www.hln.be/hln/nl/960/Buitenland/article/detail/2839023/2016/08/24/Vader-laat-dochtertje-8-rauw-hart-opeten-van-hert-dat-ze-netheeft-doodgeschoten.dhtml; geraadpleegd op 29.08.2016]; Ośmiolatka gryzie "ciepte, drżace serce” upolowanego jelenia. Myśliwi: to stara tradycja, 27 augustus 2016 [http://wyborcza. pl/1,75399,20606095,osmiolatka-gryzie-cieple-drzace-serce-upolowanego-jelenia.html; geraadpleegd op 29.08.2016].

2 Alle Engelstalige citaten over het jagende meisje zijn afkomstig uit het artikel 'She's a hunter now', Women in the World in association with the New York Times, 27 augustus 2016.

${ }^{3}$ Danny Prater, 8-Year-Old Girl Bites Into the Heart of a Deer She Shot for Fun, 25 augustus 2016 [http://www.peta.org/blog/girl-bites-raw-dead-deer-heart-new-zealand-hunting-post/; geraadpleegd op 29.08.2016]. 
hypocrieten die heel veel ophef over de beschreven situatie maken, maar tegelijk geen problemen hebben met het dierenleed binnen de intensieve veehouderij.

Interessant is dat gebeurtenissen als deze vragen oproepen die verschillende sociale en culturele spanningen aan het licht brengen. Men vraagt zich af of het kind inderdaad in staat is om te doden. Werd het meisje ertoe gedwongen en is zij zich daar eigenlijk bewust van? Wat voor voorbeeld krijgt zij van haar vader? En: wie is hier dierlijk en primitief? Mag men een dier voor ontspanning en vermaak doden? Wat zou beter zijn - jagen voor nut of voor vermaak? Hebben dieren in het wild het beter dan die uit megastallen? Zijn dieren ons eigendom? Het wordt duidelijk dat de gebeurtenis in Nieuw-Zeeland veel hedendaagse problemen raakt: ecologie, dierenbescherming, consumptisme en industriële veeteelt. Al deze kwesties zijn exponenten van een diepgaand spanningsveld tussen mens en dier, cultuur en natuur, volwassene en kind, nut en vermaak. En het is vooral de relatie tussen mens en dier die sinds Aristoteles' zoölogie de discussie over de plaats van mensen binnen het dierenrijk heeft gedomineerd.

Ook in de vroegmoderne tijd heeft men veel pogingen ondernomen om de mens te definiëren nadat het door de ontwikkeling van de vergelijkende anatomie in de zestiende eeuw steeds moelijker was geworden om de dierlijke aard van de mens te ontkennen. ${ }^{4}$ Er werden steeds meer systematische classificaties opgesteld die de kennis over de wereld organiseerden. ${ }^{5}$ Die visies op dieren en mensen vonden niet alleen hun weerklank in wetenschappelijke geschriften, maar ook in zestiende- en zeventiende-eeuwse literaire werken en de beeldende kunst. ${ }^{6}$ De taal van de culturele teksten en de manier waarop dieren erin worden gerepresenteerd zijn kwesties die in het onderzoek van ecocritici centraal staan. Als theoretisch discours houdt de ecokritiek zich bezig met natuur-representaties en symbolische constructen van dieren die in cultuuruitingen tevoorschijn komen. ${ }^{7}$ In dit artikel zal ik me buigen over maatschappelijke beelden van dieren die in de Nederlandse vroegmoderne literatuur voorkomen, met name van slachtdieren. Bijzonder interessant vind ik de manier waarop de representaties van landbouwdieren in de discussie over de mens en diens positie in de natuurlijke wereld worden gebruikt.

De dierenthematiek is eigenlijk alleen incidenteel aangesneden door Nederlandse literatuurhistorici. ${ }^{8}$ In 2007 verscheen het artikel van de literatuurhistoricus

${ }^{4}$ Zie Schiebinger 1993, 385.

5 Verheyen 2007, 128.

${ }^{6}$ Voor de bespreking van verschillende dierenrepresentaties in de Nederlandse vroegmoderne literatuur en schilderkunst zie bijvoorbeeld: Devisscher 2007 en Koppenol 2007. Verderop in dit artikel worden de teksten wat uitvoeriger besproken.

7 Zie hierover: Glotfelty 1996, xxii en Bertens 2014, 224.

${ }^{8}$ Meer aandacht trokken de dierenthematiek en de ecokritische reflectie van onderzoekers op het gebied van de hedendaagse literatuur. Zie bijvoorbeeld: Kusters 2008; Fraipont 2014; Sedláčková 2015. 
Johan Koppenol dat 'a first inventory of animals in Dutch poetry' presenteert. ${ }^{9}$ Zijn aandacht gaat uit naar de plaats en de rol van dieren in de Nederlandse maatschappij zoals gerepresenteerd in verschillende poëticale genres uit de periode 1550-1700. Koppenol verduidelijkt dat het niet alleen de christelijke visie op de natuur was als 'the work of God and therefore a source of (moral) knowledge' die haar sporen in de contemporaine literatuur heeft achtergelaten, maar ook destijdse wetenschappelijke onderzoeken en ontdekkingen van exotische dieren in nieuwe werelden. ${ }^{10}$ In 2007 kwam ook de catalogus Wonderlycke dieren op papier in de tijd van Plantin uit ter gelegenheid van een gelijknamige tentoonstelling in het Museum Plantin-Moretus te Antwerpen. ${ }^{11}$ In een zevental bijdragen worden representaties en symbolische betekenissen van verschillende dieren - zoals apen, zeemonsters en vreemde vogels - in vroegmoderne wetenschappelijke traktaten, literaire teksten en beeldende kunst behandeld. In het nawoord geeft de Antwerpse onderzoeker op het gebied van de biologie en milieueducatie, Rudi Verheyen, een ecokritische reflectie. ${ }^{12}$ Hij betoogt dat het onderzoek naar de zestiende- en zeventiende-eeuwse benadering van dieren ons meer inzicht geeft in mogelijke factoren van de hedendaagse achteruitgang van de biodiversiteit. ${ }^{13}$ In de Renaissance bleven westerse samenlevingen hun heerschappij voeren over verschillende gebieden, inclusief de dierenwereld, ondanks de ontdekkingsreizen waardoor de westerse gemeenschappen met veel onbekende fauna en flora, plaatsen en mensenrassen werden geconfronteerd en de superieure positie van de Europese, blanke christen aan het wankelen werd gebracht. ${ }^{14}$ Men ging steeds van de gedachte uit dat dieren er voor de mens zijn. 'Ze worden bejaagd, doodgeknuppeld, opgegeten, gebruikt als kledij of als sieraad, als moraliserend object waarin menselijk gedrag wordt geprojecteerd', schrijft Verheyen over de houding van de mens tegenover dieren in de Renaissance. ${ }^{15}$ De onderzoeker stelt dat dit antropocentrisme tot op vandaag 'de overheersende benadering' blijft. ${ }^{16}$ Het gevolg is dat er sinds 1600 honderden dier- en plantensoorten helemaal zijn verdwenen en duizenden andere soorten met uitsterven worden bedreigd. ${ }^{17}$ Zo toont Verheyen aan hoe de thematiek van het dier in de vroegmoderne periode bij de actualiteit aansluit.

In dit artikel neem ik representaties van slachtdieren uit de Nederlandse vroegmoderne literatuur als vertrekpunt voor de discussie over maatschappelijke denkbeelden die voor onze postmoderne benadering van dieren bepalend zijn.

${ }^{9}$ Koppenol 2007, 452.

${ }^{10}$ Koppenol 2007, 526.

11 Devisscher 2007.

12 Verheyen 2007.

13 Verheyen 2007, 125.

14 Verheyen 2007, 127.

15 Verheyen 2007, 127.

16 'Antropocentrisme blijft de overheersende benadering. Respect voor de natuur, respect voor alle levensvormen ongeacht hun nut, schoonheid of wat dan ook (ecocentrisme) groeit de laatste decennia, maar blijft beperkt en weinig verspreid.': Verheyen 2007, 136.

17 Verheyen 2007, 130-133. 
Onze hedendaagse discussiepunten, zoals dierenwelzijn of veranderingen in het natuurlijk milieu, vormen een belangrijk onderzoeksterrein van de ecokritiek. Deze leesmethode richt zich niet alleen op de manier waarop de natuur en onze relaties daartoe in de cultuur worden gerepresenteerd, maar ook op onze, soms verborgen, denkschema's die direct of indirect tot deze milieuproblemen hebben geleid. ${ }^{18}$ Tot de gevaarlijkste denkbeelden behoort volgens ecocritici de wijdverspreide overtuiging dat 'the human species has a right to use, and even exploit, nature because of its place in either a divinely sanctioned or 'natural' hierarchy'. ${ }^{19}$ Deze benadering is goed zichtbaar in het activist ecocriticism - een onderzoeksgebied gepropageerd door wetenschappers die de vroegmoderne Engelstalige literatuur bestuderen, met name het werk van Shakespeare. ${ }^{20}$ In zijn artikel 'Theory from the Fringes: Animals, Ecocriticism, Shakespeare' uit 2007 betoogt de literatuurhistoricus Simon C. Estok dat de actieve leesmethode van vroegmoderne teksten, inclusief canonieke toneelstukken van Shakespeare, helpt 'to effect real world changes through scholarly discussions'. ${ }^{21}$

Naast ecocritici leggen ook New Historicists de nadruk op de actualiteit van het historisch onderzoek. ${ }^{22}$ Ook voor hen 'geldt dat het historisch onderzoek per definitie relationeel moet zijn: het verleden is verleden in functie van het heden en vice versa', stelt de Gentse literatuurwetenschapper Jürgen Pieters in zijn boek

18 Bertens 2014, 230.

19 Bertens 2014, 230.

20 Zie hierover: Bruckner \& Brayton 2016 en Estok 2007.

${ }^{21}$ Estok 2007, 70. De actieve ecokritiek staat in Estoks onderzoeksveld centraal. Zie bijvoorbeeld zijn nawoord in de bundel Ecocritical Shakespeare: Estok 2016.

${ }^{22}$ Het begrip New Historicism werd door de Amerikaanse literair criticus Stephen Greenblatt gebruikt ter aanduiding van zijn teksten over de Engelse Renaissance. Voor de ontwikkeling van de nieuwe tendens was de publicatie van Greenblatt's Renaissance Self-Fashioning: From More to Shakespeare (1980) en Shakespearean Negotiations (1988) van groot belang. Hoewel de term New Historicism in Renaissance Self-Fashiong nog niet viel, genoot het boek enorme populariteit en werd gerekend tot de belangrijkste teksten op het gebied van het historische onderzoek. Zijn leesmethode duidde Greenblatt hier nog als 'poetics of culture' wat betekent dat hij op zoek ging naar 'de complexe interactie tussen allerhande maatschappelijke praktijken die vertegenwoordigers van een cultuur in staat stellen betekenis te geven aan de werkelijkheid waarin ze functioneren' (Pieters 2011, 147). Pas in 1982 werd de term voor het eerst door Greenblatt gebruikt. Hij stelde toen een themanummer van het tijdschrift Genre samen, waarin artikelen van een groep Amerikaanse literatuurhistorici staan die, net als Greenblatt, interesse had voor 'de wederzijdse verhoudingen tussen de vormelijke keuzes die auteurs van literaire werken maken (...) en de maatschappelijke omstandigheden waarin die werken hun plaats moeten vinden' (Pieters 2011, 147). Voor Greenblatt zijn de opstellen voorbeelden van een nieuwe leesmethode die in zijn inleiding op het themanummer een 'new historicism' wordt genoemd. De leespraktijk werd in Greenblatt's essaybundel Shakespearean Negotiations verder ontwikkeld. Van betekenis is hier vooral zijn inleiding waarin methodologische en theoretische beschouwingen over zijn werkwijze staan (zie Pieters 2011, 161). Over het New Historicism zie bijvoorbeeld: Veeser 1989; Pieters 2001, 2005, 2011; Skrobut 2010; Kozikowska 2011; Bertens 2014, 150-161. 
Historische letterkunde vandaag en morgen..$^{23}$ De bedoeling van een historische analyse is om verschillende aspecten van onze cultuur ter discussie te stellen. In dit opzicht lijkt de vroegmoderne periode zeer aantrekkelijk voor de New Historicists: 'het is een cultuurhistorisch moment waarin een aantal ontwikkelingen (m.b.t. individualisme, kapitalisme, globalisering) beginnen op te komen (...)', aldus Pieters. ${ }^{24}$ In het historische onderzoek wordt de hedendaagse cultuur van haar vanzelfsprekendheden ontdaan, 'in die zin dat ze zich geleidelijk begint te tonen als een verzameling van ideeën en praktijken die ergens vandaan komen - in dit geval uit een zeventiende eeuw die zo dichtbij lijkt en toch weer veraf' ${ }^{25}$

In het nu volgende probeer ik aan te tonen dat er in de Nederlandse vroegmoderne literatuur door middel van een stereotiep cultuurbeeld van slachtdieren een visie op de mens wordt geschetst, die bedoeld wordt om de heerschappij van mensen over de natuurlijke wereld en hun exploitatie van dieren duurzaam te legitimeren. Als uitgangspunt van mijn analyses neem ik het gedicht 'Kinderspel' (1618/1625) van de zeventiende-eeuwse dichter Jacob Cats (1577-1660). De dierenthematiek komt hier tot uitdrukking in de beschrijving van kinderspelen met dierlijke resten - ossenblazen en kootbenen. Het valt op dat de tegenstelling tussen mens en dier gebaseerd wordt op de oppositie tussen volwassene en kind. Hieronder zal duidelijk worden dat kinderen en dieren in Cats' gedicht een vergelijkbare rol spelen. Hun aanwezigheid roept vragen op naar de mogelijkheden en de beperkingen van de mens, naar zijn moraal en levenswijze en daarom worden ze tot dezelfde categoriegroepen gerekend. De connotaties die kinderen en slachtdieren in 'Kinder-spel' wekken en de culturele contexten waarvan ze deel uitmaken, staan in mijn bespreking centraal.

In de analyses gebruik ik het New Historicistische concept van een tekst als een mozaïek van stukjes cultuur, aangeboden door Pieters. ${ }^{26}$ Het taalgebruik is in deze visie dialogisch of intertekstueel, dat wil zeggen dat het zich bedient van woorden en betekenissen die al eerder zijn gebruikt. Het gedicht van Jacob Cats wordt door mij gezien als zo'n plaats van culturele uitwisseling waar stemmen van verschillende wetenschappelijke en socioculturele discussies elkaar doorkruisen. In de lijn van het New Historicism zal ik Cats' tekst dus contextueel benaderen en aandacht besteden aan vroegmoderne debatten over de relaties tussen mens en dier, kind en opvoeding en cultuur en natuur.

23 Pieters 2011, 88.

24 Pieters 2011, 88.

25 Pieters 2011, 89.

26 Pieters 2005, 256. Naast het concept van Pieters en zijn aandacht voor de relevantie van het historische onderzoek (2011, 88-89), zijn het ook het artikel van Simon C. Estok 2007, ideeën van Homi K. Bhabha 2010 over het koloniale discours en de interpretatie van Shakespeare's Hamlet aangeboden door Catherine Gallagher en Stephen Greenblatt 2000 die ten grondslag aan mijn artikel en de hier geformuleerde overwegingen liggen. 


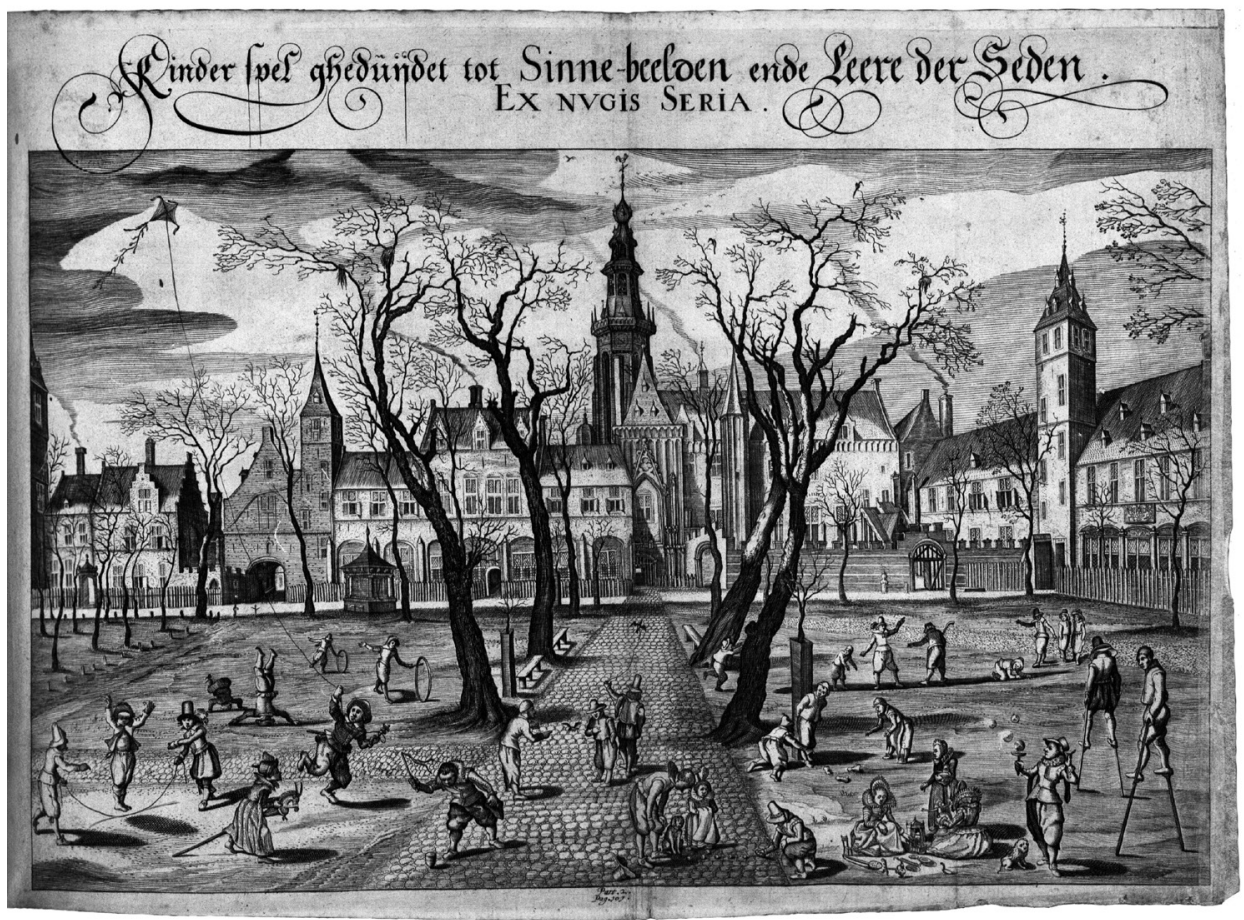

Afb. 1. Adriaen van de Venne, 'Kinder-spel gheduyt tot Sinne-beelden ende Leere der Seden. Ex nvgis seria', titelprent, in: Jacob Cats, Silenus Alcibiadis, Sive Proteus (...). Middelburg 1618. Universiteitsbibliotheek Vrije Universiteit Amsterdam, sign. XH.00091

\section{Kinderspelen en seizoenwerken: de harmonie tussen mens en natuur}

Het gedicht 'Kinder-spel' verscheen oorspronkelijk in 1618 in de emblematabundel Silenus Alcibiadis, Sive Proteus ${ }^{27}$ en vervolgens, in een uitgebreide versie, in

${ }^{27}$ De volledige titel van de bundel luidt: Silenus Alcibiadis, sive Proteus, vitae humanae ideam, emblemate trifariam variato, oculis subijcens. Deus nobis haec fecit. Het boek is samengesteld uit 51 emblemen die in drie hoofdstukken - amoureus, zedelijk-maatschappelijk en religieus - zijn verdeeld. Elk emblemata bestaat uit een illustratie voorzien van Nederlandse, Latijnse en Franse motto's, verzen die de verborgen betekenis onthullen en citaten. De talrijke verwijzingen naar de Bijbel, de kerkvaders en verschillende klassieke en contemporaine schrijvers wijzen op het polyglottische en erudiete karakter van de bundel. Cats' werk is daarom gericht op goed opgeleide lezers die met de antieke bronnen en de spreekwoorden in diverse talen vertrouwd zijn. 'Kinder-spel' is aan het einde van het tweede, maatschappelijke deel opgenomen, vóór de titelpagina van deel drie (Cats $\left.1618,106\left[\mathrm{O}^{\mathrm{v}}\right]-111\left[\mathrm{O}^{\mathrm{r}}\right]\right)$. De volledige titel van het gedicht is: 'Kinder-spel gheduyt tot sinne-beelden ende leere der zeden'. De titel van het gedicht toont expliciet aan dat de hier zinnebeeldig voorgestelde kinderspelen de zedenleer dienen. Het emblematische karakter van het gedicht is echter ook 
het didactische traktaat Houwelyck ${ }^{28}$ gepubliceerd in $1625 .{ }^{29}$ Beide versies van de tekst zijn door Adriaen van de Venne (1587/1589-1662) met een prent geïllustreerd waarop een aantal spelende kinderen zijn afgebeeld (afb. 1 en 2). Het gedicht is geheel gewijd aan kinderen en hun spelletjes, maar is niet aan kinderen

in de structuur te zien. Er wordt aan ieder kinderspel een aparte alinea gewijd die meestal uit twee delen - het beschrijvende en het duidende - bestaat en daarmee op een opbouw van een embleem lijkt. Daarnaast wordt de symbolische betekenis van de spelen door de bijbehorende, Latijnse citaten onthuld. Bovendien werden alle, in het gedicht besproken, kinderspelen door Adriaen van de Venne afgebeeld en hebben hun eigen plaats op de bijbehorende illustratie. Vanuit dit perspectief sluit het gedicht niet alleen bij de zedelijk-maatschappelijke thematiek van het tweede gedeelte aan, maar ook bij de structuur van de hier opgenomen emblemata. Het gedicht staat op: http://www.dbnl.org/ tekst/cats001sile01_01/cats001sile01_01_0122.php; geraadpleegd op 18.11.2016. Over de opbouw van de bundel zie bijvoorbeeld: Porteman 1977, 91; Luijten 1996, dl. 2, 79-83 en dl. 3, 7-10; Porteman \& Smits-Veldt 2008, 310. Over de tweeledigheid van het embleem schreef de Duitse emblematoloog Albrecht Schöne. Volgens hem bestaat het onderschrift uit twee delen: het beschrijvende en het duidende, elk waarvan een gedeeltelijke oplossing biedt. Zie hierover: Porteman 1977, 38-41, 54 en Luijten 1996, dl. 2, 42-43.

${ }^{28}$ De volledige titel van het traktaat is: Houwelyck. Dat is De gansche gelegentheyt des Echten Staets. In dit werk staat de levensweg van de vrouw centraal. Houwelyck bestaat uit zes hoofdstukken dat elk aan een ander levensstadium van de vrouw is gewijd. De laatste vier boeken - die onder de overkoepelende titel 'Christelick Huys-wijf' zijn samengebracht - vormen de kern van het traktaat en vertellen over de huwelijksplichten van bruid, vrouw, moeder en weduwe. De vier hoofdstukken worden ingeleid door twee samenspraken over de maagdelijke staat: 'Maeght' en 'Vryster'. 'Kinder-spel' staat helemaal vooraan, achter de titelprent van het boek en het voorwoord van Adriaen van de Venne (Cats 1625, I (*) $\mathrm{ijj}^{\mathrm{r}}-\left[\mathrm{I}\left(^{* *}\right) \mathrm{ij}^{\mathrm{V}}\right]$. De titel van het gedicht luidt: 'Kinder-spel. Ex nugis seria'. Het gedicht krijgt in het traktaat een nieuwe, uitgebreide vorm en wordt door een vernieuwde versie van Van de Venne's prent voorzien. Bovendien zijn er structurele en inhoudelijke veranderingen aangebracht waardoor het 'Kinder-spel' bij het gehele traktaat aansluit. Onder andere worden er nieuwe spelvormen aan toegevoegd - zoals blindemannetje, schuttersparade, spel met poppengoed en een klein huisraad - die op toekomstige bezigheden van jongens en meisjes betrekking hebben en daarmee het gedicht aan de matrimoniale thematiek van het traktaat koppelen. Door middel van de gewijzigde titel ziet men bovendien dat Cats afscheid neemt van de emblematische oorsprong van het gedicht. Hoewel het Erasmiaanse opschrift Ex nugis seria [Uit scherts ernst] ook hier op het trekken van serieuze lessen uit beuzelachtige zaken wijst, is er geen expliciete verwijzing naar het zinnebeeldige karakter van de kinderspelen. Daarnaast zijn de Latijnse citaten, die in de primaire versie bij de beschrijving van elk kinderspel staan, dit keer weg. De diepere duiding van de spelen wordt direct in de tekst en niet in de marginalia verduidelijkt. De algemene opzet van het 'Kinder-spel' blijft echter hetzelfde. Ook hier dient het gedicht stichting van de lezer door hem/haar menselijke tekortkomingen voor ogen te stellen. Het weglaten van erudiete, Latijnse citaten kan verbonden zijn met het beoogde publiek van het huwelijksboek. In zijn voorrede bij het deel 'Bruyt' schrijft Cats $\left.\left(1625,{ }^{*}{ }^{\mathrm{ij}}{ }^{\mathrm{V}}\right]\right)$ dat hij met het oog op vrouwelijke lezers de taal en de stijl van het traktaat aan de alledaagse thematiek - het huwelijks-en gezinsleven - probeerde aan te passen. De tekst staat op: http://www.dbnl.org/tekst/cats001houw01_01/cats001houw01_01_0003.php; geraadpleegd op 18.11.2016. Over de structuur van het huwelijkstraktaat zie bijvoorbeeld: Te Winkel 1923, 352; Meertens 1943, 268; Ten Berge 1979, 78-94 en Sneller \& Thijs 1993, 142. Over Cats' taalgebruik in Silenus Alcibiadis en Houwelyck zie: Meertens 1943, 289-290.

${ }^{29}$ Voor de bespreking van de drukgeschiedenis van het gedicht zie: Kozikowska 2016, 111115.

Neerlandica Wratislaviensia 26, 2016

(C) for this edition by CNS 
gericht. Cats richt zich over hun hoofden heen tot volwassenen; hij beschrijft de kinderspelen als symbolen van menselijke deugden en zwakheden en besteedt aandacht aan de relaties van mensen onderling en hun verhouding tot God. De allegorische betekenis van de spelen dwingt de lezer tot het nadenken over eigen gedrag, zoals de eerzucht uitgebeeld door het oplaten van een vlieger ${ }^{30}$ of de blinde verliefdheid getoond aan de hand van het blindemannetje ${ }^{31}$. Op deze manier komt in 'Kinder-spel' ook het spelen met dierlijke resten - met een ossenblaas en koten - aan de orde. ${ }^{32}$

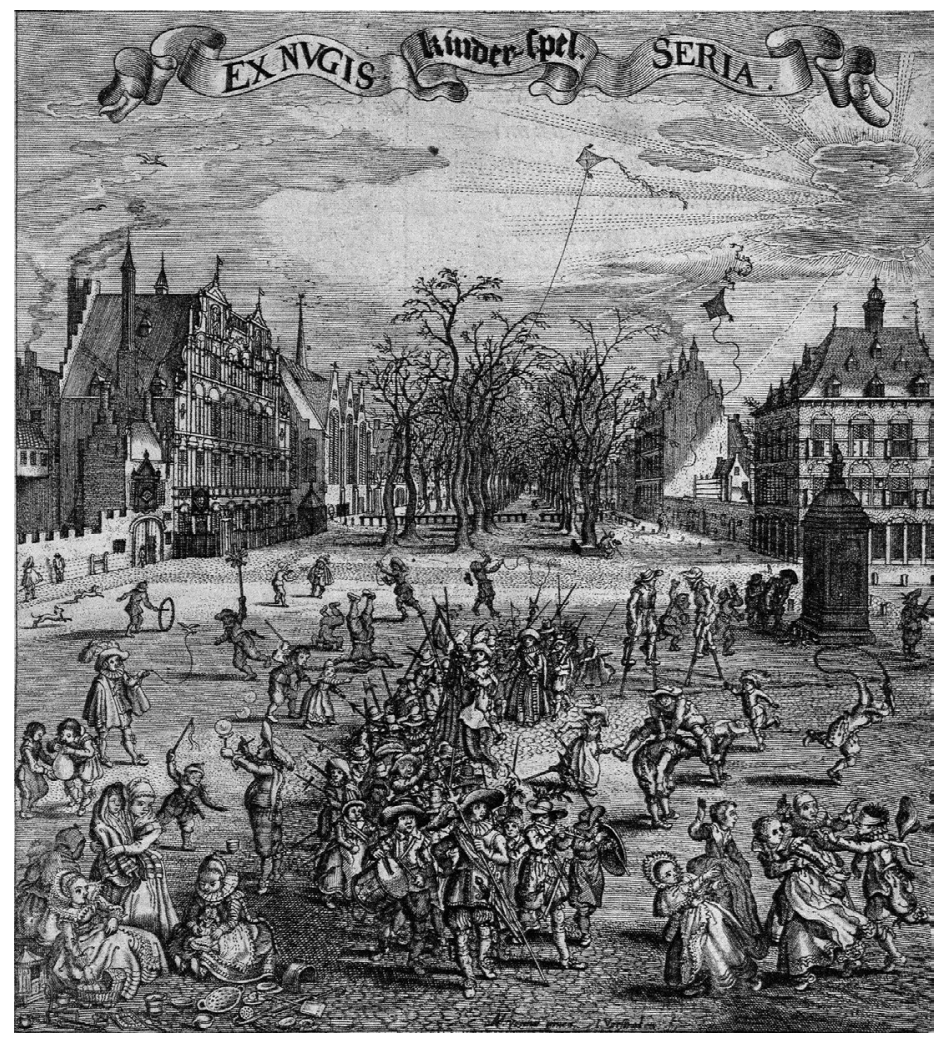

Afb. 2. Adriaen van de Venne, 'Kinder-spel. Ex nvgis seria', titelprent, in: Jacob Cats, Houwelyck. Dat is De gansche gelegentheyt des Echten Staets. Middelburg 1625. Universiteitsbibliotheek Vrije Universiteit Amsterdam, sign. XH.00117

${ }^{30}$ Cats $1625,\left[\mathrm{I}(* *)^{\mathrm{v}}\right]$.

${ }^{31}$ Cats $1625,\left[\mathrm{I}(*) \mathrm{iij}^{\mathrm{V}}\right]-\mathrm{I}(*) \mathrm{iiij}^{\mathrm{r}}$.

${ }^{32}$ Het kootspel komt in beide versies van Cats' gedicht voor (Cats 1618, $107 \mathrm{O}^{\mathrm{r}}-108$ [O2 $\left.{ }^{\mathrm{v}}\right]$ en $\left.1625, \mathrm{I}\left({ }^{* *}\right)^{\mathrm{r}}\right]$ ) en het spel met een ossenblaas alleen in de uitgebreide versie (Cats $1625, \mathrm{I}\left({ }^{*}\right)$ iiij $^{\mathrm{r}}$-[I (*) iiij $\left.^{\mathrm{V}}\right]$. 
Het thema van het spel met dierlijke resten maakt deel uit van een langere, literaire en iconografische traditie, waarin kinderspelen in het kader van seizoenwerken van volwassenen worden gepresenteerd. Dit soort speelgoed kostte niets en was net als andere zaken uit de natuur, zoals stenen, noten of bomen, relatief gemakkelijk te verkrijgen en bood populair vermaak. ${ }^{33}$ Eeuwenlang werd de aanwezigheid van spelende kinderen tijdens het slachten en het ontweien van dieren niet vreemd gevonden. Niet alleen bekeken de kleinsten met grote belangstelling het werk van volwassenen, ze leerden ook hoe ze later zelf zouden gaan slachten en wachtten met ongeduld op buit in de vorm van slachtafval dat als speelgoed kon dienstdoen. Kinderen speelden met varkens- of ossenblazen en maakten muziek met botten van hoefdieren, zoals fluiten vervaardigd van ezelsbotten, en gebruikten beentjes om te koten. ${ }^{34}$

Het feit dat de dieren eerst moesten sterven voordat het speelgoed beschikbaar kwam, zorgde voor een natuurlijk en tijdgebonden verband tussen deze vorm van kinderspel en de slacht, die traditioneel in de herfst en in de vroege winter plaatsvond. De kinderspelen op de taalrijke zestiende- en zeventiende-eeuwse afbeeldingen van slachtscènes stemmen ermee overeen. Het valt op dat de kinderspelen met bepaald seizoenwerk van volwassenen samenvallen. In zestiendeeeuwse Vlaamse manuscripten fungeren het koten en het spel met een ossenblaas als 'spel van de maand' oktober waarin traditioneel de slacht van ezels en runderen (ossen en koeien) plaatsvond (afb. 3, 4 en 5). ${ }^{35}$

33 Zie hierover: Pluis 1979, 9. Over verschillende soorten speelgoed en materiaal waarvan het kinderspeelgoed werd gemaakt zie: Willemsen 2007.

${ }^{34}$ Kinderen speelden vooral met beentjes uit de hiel van rund of schaap. De eerste variant heet 'koten' en werd voornamelijk door jongens gespeeld. De andere is in hoofdzaak een meisjesspel en wordt 'bikkelen' genoemd. Zie hierover: Drost 1914, 100-101. In Cats' gedicht treedt alleen het kootspel op daarom wordt het bikkelspel in dit artikel buiten beschouwing gelaten. Verderop wordt het koten uitvoerig besproken.

${ }^{35}$ Het gaat om een groep rijkversierde zestiende-eeuwse Vlaamse handschriften vervaardigd in het atelier van Simon Bening in Brugge en Gerard Horenbout in Gent. Ze bevatten geïllustreerde kalenders met series kinderspelen uit breviaria en getijdenboeken. De functie van de kalenders was voornamelijk om de lezers tot het verder lezen aan te sporen. Daarom zijn de bladen vol van decoratieve elementen, zowel religieuze als wereldlijke, bv. bijbelstof en heiligen, maar ook sterrenbeelden en seizoenwerken. Tot dit laatste type voorstellingen rekent men niet alleen scènes van dagelijkse bezigheden op de boerderij, maar ook activiteiten karakteristiek voor volksfeesten en christelijke gedenkdagen of juist voor kinderspelen die met een bepaald jaargetij verbonden waren. Zie hierover: Hindman 1981; Willemsen 1998, 231-257; Orrock 2010, 75. De term 'spel van de maand' komt onder andere in het onderzoek van Willemsen 1998 en 2005 voor. Deze kunsthistorica merkt op dat kinderspelen over het hele jaar verspreid konden worden want ze werden in grote mate door jaargetijden bepaald. Op die wijze werden bepaalde kinderspelen aan een concrete tijd van het jaar gekoppeld, bijvoorbeeld: sneeuwballen aan de winter en vlinders vangen aan de zomer. Het schema van het 'spel van de maand' wordt dus gegrond op de binding van bepaalde spelletjes met jaargetijden, een feest of gewoonte. De term 'spel van de maand' vinden wij ook in het proefschrift van Amy Orrock 2010. In het bewust wijzen op de analogie tussen de werkzaamheden en de spelen typerend voor een bepaalde maand is volgens Orrock een artistieke conventie zichtbaar zowel in de vermelde 


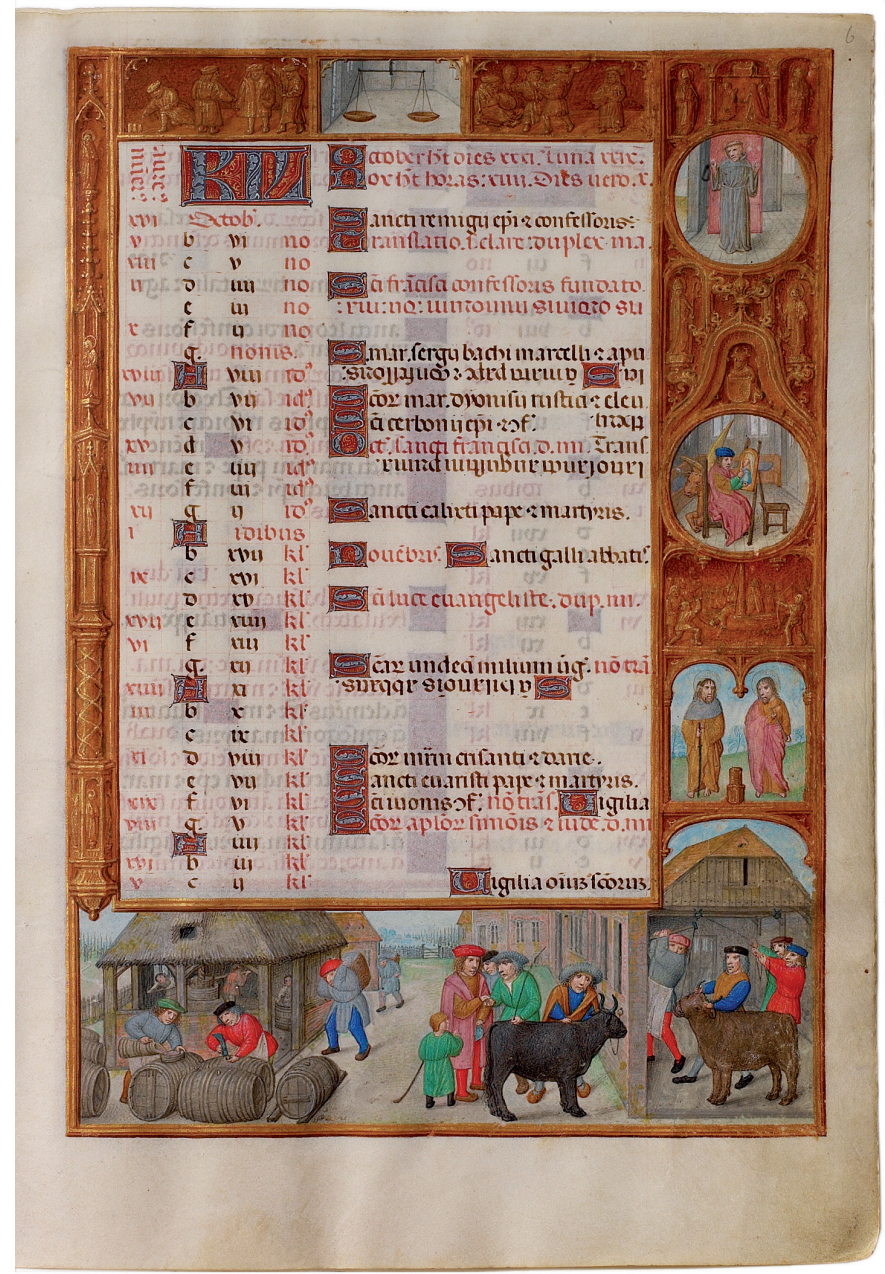

Afb. 3. Kalenderblad van de maand oktober, in de ondermarge een afbeelding van de slacht van runderen en in de bovenmarge een illustratie van het kootspel en ossenblazen, Breviarium Mayer van den Bergh, ca. 1510, Antwerpen, Museum van den Bergh, Cod. 946, fol. $6^{\mathrm{r}}$

Het koten is een spel dat al in de Oudheid werd gespeeld. ${ }^{36}$ In tegenstelling tot het dobbelen vereiste het kootspel een zekere behendigheid van de spelers, winst of verlies hing niet alleen af van toeval. Het koten bleef tot de negentiende eeuw één van de populairste jongensspelen in Nederland en men kende allerlei verschil-

kalenders als op Bruegels paneel Kinderspelen (1560). De parallel tussen de werken en de spelen van de maand merkte Sandra Hindman al op in haar artikel uit 1981.

${ }^{36}$ Kootbenen als speelgoed gebruikten onder meer de Oude Grieken en Romeinen, zie Hallema \& Weide 1943, 111. 
lende vormen daarvan. ${ }^{37}$ De Zuid-Nederlandse handschriften tonen tenminste twee manieren waarop gekoot kon worden. De eerste spelvorm doet denken aan het kegelspel: er wordt een aantal koten op een rij gezet, waarnaar een speler met een koot gooit. De koten die omvallen worden door de speler gewonnen. Deze spelvariant is afgebeeld in het Spielbuch (1500), het Breviarium Mayer van den Bergh (ca. 1510, zie afb. 3), het Breviarium van Eleonora van Portugal (ca. 1510), het Spinola-getijdenboek (ca. 1515) en het Golfboek (ca. 1520, zie afb. 4). ${ }^{38}$
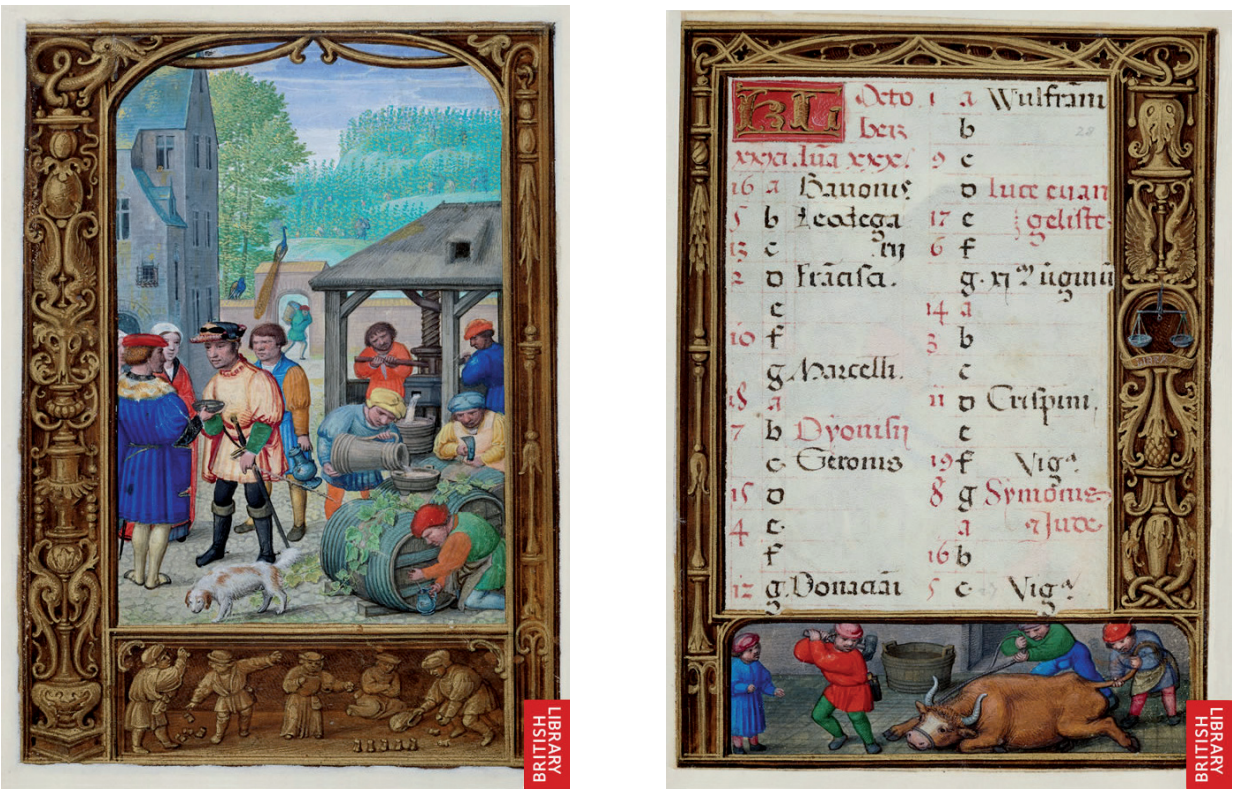

Afb. 4 en 5. Kalenderbladen van de maand oktober, in de ondermarge links een groep jongens die met koten spelen en rechts - de slacht van een os, Golfboek, ca. 1520, London, (C) British Library Board, Add. MS 24098, fol. $27^{\mathrm{v}}-28^{\mathrm{r}}$

De tweede versie vereist van de spelers een speciale werptechniek: het gaat erom de koten zodanig te gooien dat ze op een bepaalde zijde komen te liggen. De winnaar krijgt meestal de koten van zijn tegenspelers. Dit spel is weergegeven in het Breviarium van Eleonora van Portugal, het Spinola-getijdenboek en het Golfboek (zie afb. 4).$^{39}$ Beide spelvarianten worden bovendien op de kinderspel-prent van Van de Venne gespeeld (afb. 6 en 7). De eerste spelvorm is afgebeeld op de gra-

${ }^{37}$ Voor de bespreking van verscheidene spelvormen zie: Hallema \& Weide 1943, 111-112 en Pluis 1979, 174-176.

38 Spielbuch, ca. 1500, München, Bayerische Staatsbibliothek, Clm 28346; Breviarium Mayer van den Bergh, ca. 1510, Antwerpen, Museum van den Bergh, Cod. 946; Spinola-getijdenboek, ca. 1515, Los Angeles CA, J. Paul Getty Museum, MS 83; Golfboek, ca. 1520, London, British Library, Add. MS. 24098. Zie Orrock 2010, 106 en 308.

39 Zie Orrock 2010, 107. 
vure bij de uitgebreide versie van Cats' 'Kinder-spel' uit 1625 en de tweede - op de prent bij de primaire versie uit $1618 .^{40}$
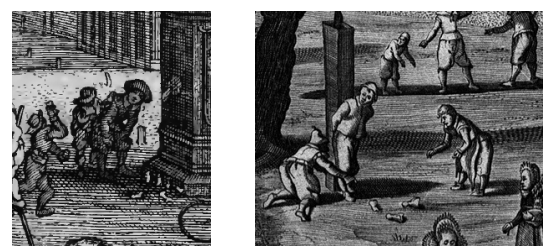

Afb. 6 en 7. Varianten van het kootspel op de kinderspel-prenten van Adriaen van de Venne; links - detail uit 'Kinder-spel. Ex nugis seria', 1625; rechts - detail uit 'Kinder spel gheduyt tot Sinne-beelden ende Leere der Seden. Ex nugis seria', 1618

Varkens werden meestal in november en december, na de eerste vorst, geslacht, zodat het vlees bij lage temperatuur kon worden bewaard. ${ }^{41}$ Kinderen konden de varkensblaas met een riet of stro opblazen en dichtknopen - ze hadden dan een ballon. ${ }^{42}$ Als ze de blaas een tijd lieten rusten en drogen hadden ze een bal; soms deden ze er een paar erwten in, waardoor ze een rammelaar kregen. De bal van dierenblaas kon worden geschopt of gegooid. Naast varkensblazen waren ook de blazen van ossen en ezels geschikt om mee te spelen. Het spel met de ossenblaas wordt weergegeven in het Breviarium Mayer van den Bergh (zie afb. 3). ${ }^{43}$ De varkensblaas treedt als 'spel van de maand' op in zestiende- en zeventiendeeeuwse prentenseries die uit de traditie van Zuid-Nederlandse handschriften stammen, bijvoorbeeld gravures met typische decemberwerkzaamheden door Adriaen Collaert (1560-1618, afb. 11), Pieter van der Borcht (1545-1608, afb. 10) en Aegidius Sadeler (1570-1629, afb. 9).

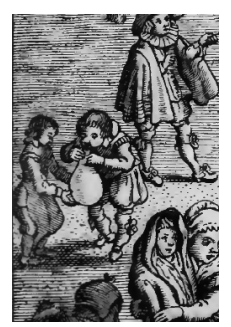

Afb. 8. Kinderspel met een ossenblaas op de prent van Adriaen van de Venne, detail uit 'Kinder-spel. Ex nugis seria', 1625

\footnotetext{
${ }^{40}$ Cats $1618,106\left[\mathrm{O}^{\mathrm{v}}\right]-107 \mathrm{O}^{\mathrm{r}}$ en $1625, \mathrm{I}\left({ }^{*}\right) \mathrm{iij}^{\mathrm{r}}$.

${ }^{41}$ Zie hierover: Orrock 2010, 102.

42 Voor de bespreking van spelvormen met de blaas zie Pluis 1979, 256-257.

${ }^{43}$ Zie Orrock 2010, 308.
} 


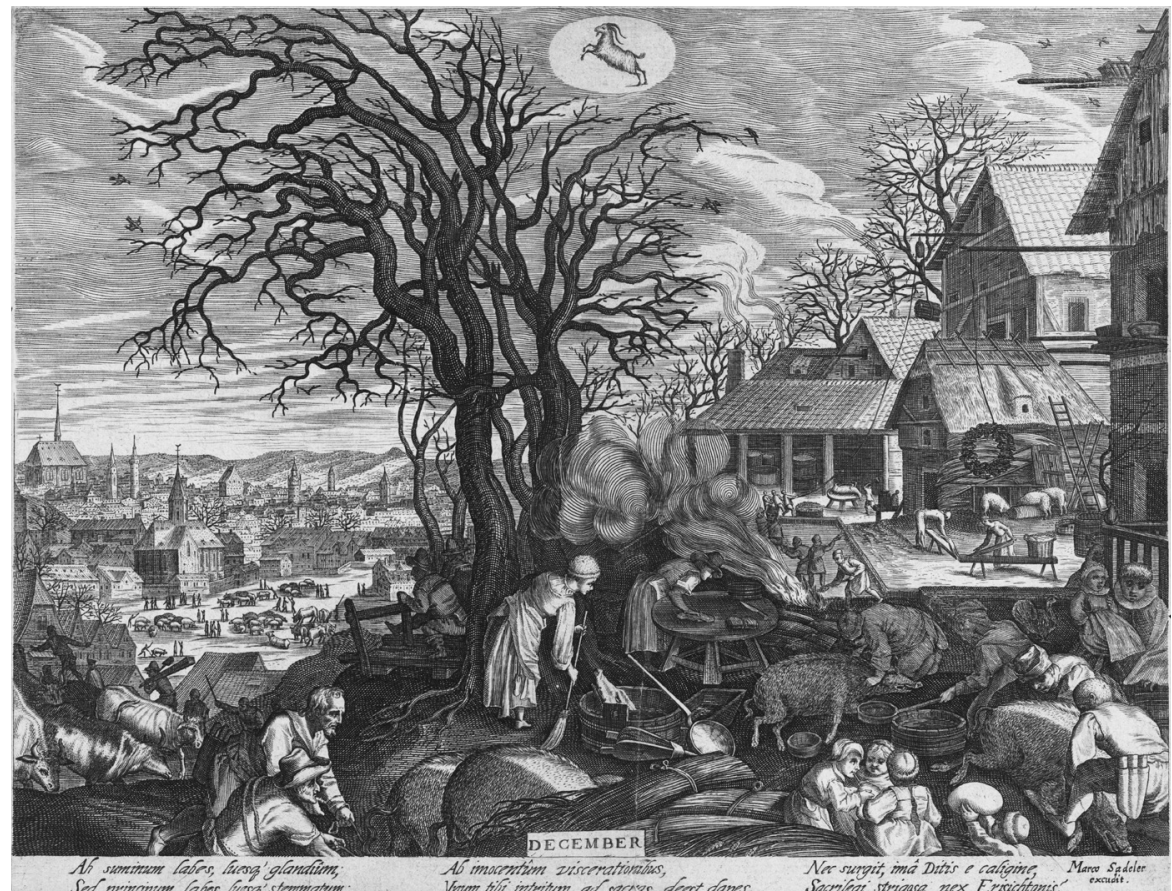

Afb. 9. Kinderspel met een varkensblaas op de prent van Aegidius Sadeler naar ontwerp van Pieter Stevens I, December, 1607/1624-ca. 1650. Gravure, 21.2x28.5 cm. Rijksmuseum Amsterdam, RP-P-OB-7048, C Publiek Domein

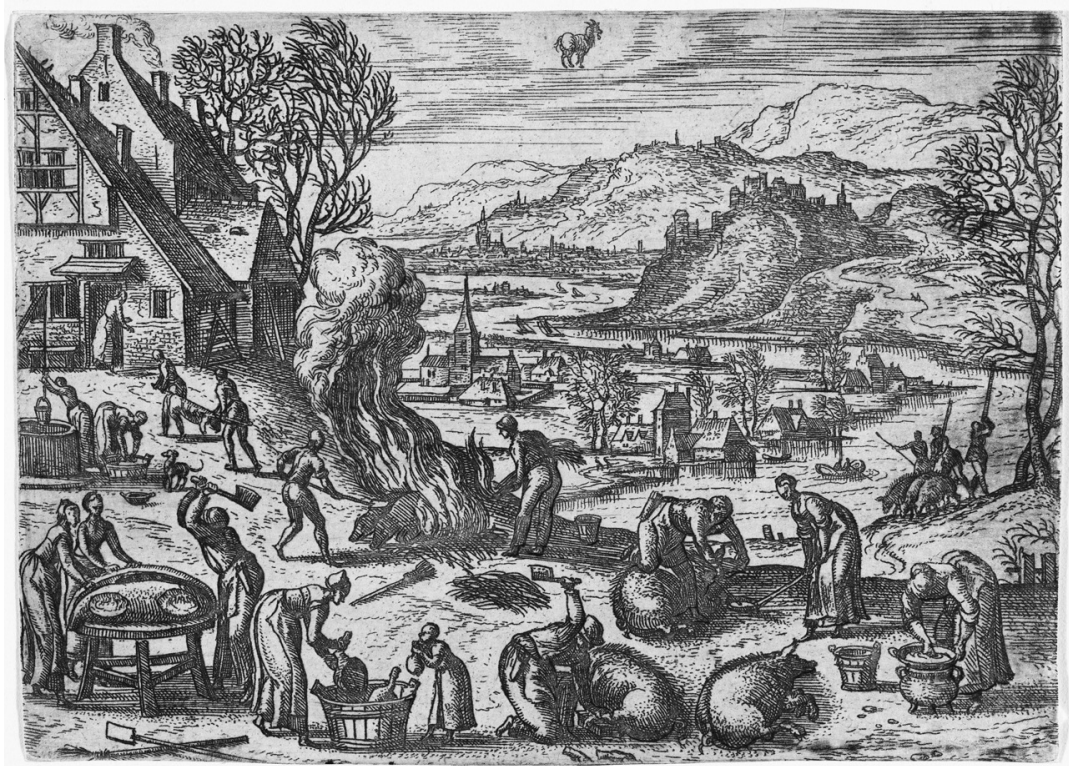

Afb.10. Kinderspel met een varkensblaas op de prent van Pieter van der Borcht, December, 1545-1608. Ets, 16.6x12.0 cm. Rijksmuseum Amsterdam, RP-P-1887-A-11581, (C) Publiek Domein 
Kinderen met een ossenblaas zijn bovendien afgebeeld door Adriaen van de Venne op de kinderspel-prent uit 1625 (afb. 8). ${ }^{44}$ Tezamen geven de spelen en de werken de cyclus weer van de natuur en daarmee ook van het menselijk leven. De slacht van dieren verschafte mensen vlees om de winter door te komen - en kinderen kregen nieuw speelgoed. Zo ontstaat er een spannende verhouding tussen de vreugde van de grote en kleine mens en de dood van het dier, alsook tussen het verlangen naar spel van kinderen dat de overhand heeft en het nuttige werk van volwassenen.

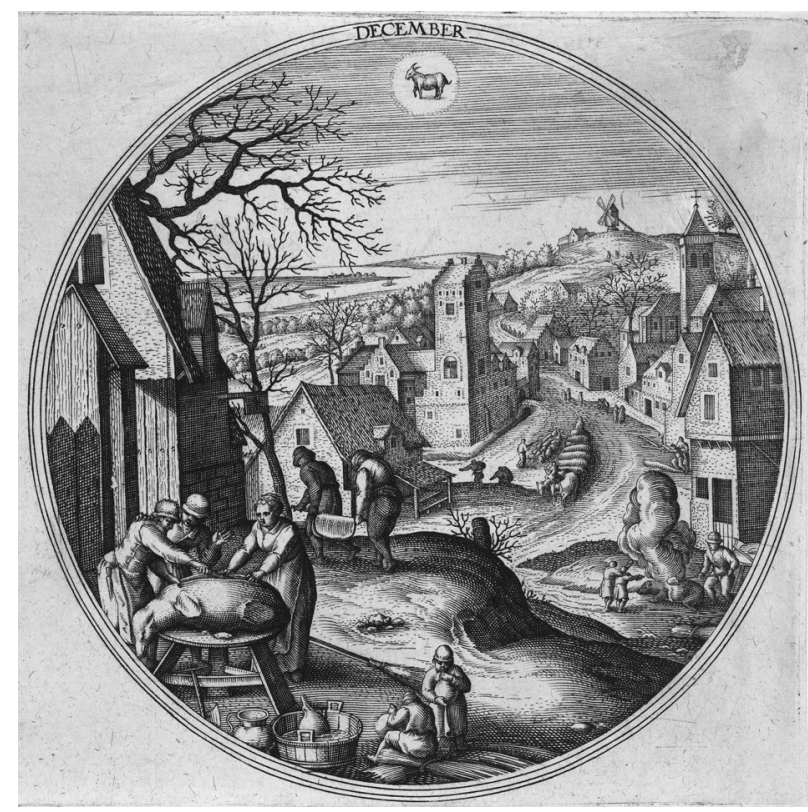

Afb. 11. Kinderspel met een varkensblaas op de prent van Adriaen Collaert naar ontwerp van Hans Bol, December, 15781582. Gravure, $14.1 \times 15.0 \mathrm{~cm}$. Rijksmuseum Amsterdam, RP-P1900-A-21940, (C) Publiek Domein

Het is opmerkelijk dat deze spanning ook in het gedicht van Jacob Cats zichtbaar is. Er wordt met klem benadrukt dat de kinderen de slachttijd met ongeduld afwachten want ze hopen nieuw speelgoed te krijgen. In de beschrijving van spelletjes met een ossenblaas lezen wij:

Dit kint heeft langen tijt gevvacht,

En veel en dickmaels overdacht,

Vvanneer de slagh-tijt komen wou,

En datmen ossen bollen [=slachten, JK] sou (....). ${ }^{45}$

44 Cats $1625, \mathrm{I}\left(^{*}\right) \mathrm{iij}^{\mathrm{r}}$.
${ }^{45}$ Cats $1625, \mathrm{I}\left(^{*}\right) \mathrm{iiij}^{\mathrm{r}}$. 
Zo wordt duidelijk dat het vermaak van kinderen van de dood van het dier afhankelijk is. Hetzelfde geldt ook voor het verkrijgen van kootbenen die jongens voor verschillende werpspelen gebruikten. In de beschrijving van het kootspel lezen wij dat zolang de os rustig leeft de straten niet door vrolijk spelende jongens worden bezet. Pas het slachten van het dier betekent dat de kinderen zich met het nieuwe speelgoed op straat kunnen vermaken:

Maer raeckt het beest eens uytten stal,

En doet het dan een drouven val,

Soo wort terstond sijn innich been

Den jongers op de straet gemeen,

Die maecken dan een groot geraes

En met de koot, en met de blaes. ${ }^{46}$

In het volgende fragment wordt de lezer geattendeerd op opvallend gedrag van de jongens: zij besteden al hun aandacht aan botten en blazen in plaats van aan het vlees en vet waaraan het geslachte dier zo rijk is.

Edoch sijn oogh en gans gepeys

En sach niet op het osse-vleys,

Niet op het smeir, niet op het roet,

Ten dacht niet om te sijn gevoet (...). ${ }^{47}$

Deze handelwijze is voor de dichter moeilijk te begrijpen en aanleiding tot bespiegelingen, zeker wanneer hij bedenkt hoe kwetsbaar het speelgoed is, zoals een ballon gemaakt van een blaas die op elk moment kan klappen:
Maer al dat groot en lang geraes
En was alleen maer om de blaes,
Die jaeght het nu vol schrale wint,
En daer ist dat het vreughde vint;
Maer prickt eens met een kleyne spel,
Terstont soo slinckt het bol gesvvel. ${ }^{48}$

De kwetsbaarheid van een ossenblaas en het feit dat het verkrijgen van dit soort speelgoed afhangt van het slachten van een dier vormen een uitgangspunt voor verdere overwegingen over de vergankelijkheid van het menselijk bestaan en aardse goederen. ${ }^{49}$ Cats trekt een vergelijking tussen de kinderen die geïnteres-

${ }^{46}$ Cats $1625, \mathrm{I}(* *)^{\mathrm{r}}$.

${ }^{47}$ Cats $1625,\left[\mathrm{I}(*)\right.$ iiij $\left.^{\mathrm{v}}\right]$.

48 Cats $1625,\left[\mathrm{I}(*)\right.$ iiij $\left.^{\mathrm{v}}\right]$.

${ }^{49}$ Het motief is door Cats echter vaker benut. In het embleem 'Op 't gesichte van een jongen met de blase spelende' uit de bundel Invallende gedachten, op voorvallende gelegentheden (1655) geeft de dichter door middel van het kinderspel gestalte aan de kortstondigheid van de menselijke roem en het aardse leven. Zie Cats 1862, 559-560. Het embleem staat op: http://www.dbnl.org/tekst/ cats001jvan03_01/cats001jvan03_01_0269.php; geraadpleegd op 18.11.2016. De realisatie van het thema vinden we ook bij Jan Luyken (1649-1712) die in zijn embleem 'De Blaas' uit Des menschen begin, midden en einde (1712) een vergelijking trekt tussen de wereld en de opgeblazen blaas 
seerd zijn in spel en plezier en volwassenen die hun aandacht van het geestelijk leven laten afleiden en aan wereldse genoegens gehecht zijn. Net als de kinderen die geen oog hebben voor het nuttige vlees, kunnen ze waardevolle zaken niet van onbetekenende onderscheiden.

VVat isser menich ydel mensch

Die streckt sijn lust en ganschen wensch

Dat yemant, daer hy t'oogh op heeft,

Van nu sijn tijt had uyt-geleeft!

Niet om te deelen in het goet,

VVant hy en is niet van het bloet,

Maer op dat hy bekomen mocht

Een schrale wint, een kleyne locht. ${ }^{50}$

Interessant is het feit dat de os vlak vóór de slacht ten tonele wordt gevoerd. Het dier wordt beschouwd met het oog op zijn innerlijke organen die slechts postuum beschikbaar zijn. Zijn vlees is voedsel voor mensen en zijn botten en een blaas fungeren als een bron van vreugde voor kinderen die ermee spelen. Er wordt verzwegen dat de os tijdens zijn leven als landbouwdier wordt gebruikt en zijn botten nodig heeft om de ploeg te trekken. Op die manier wordt er gesuggereerd dat het dier zijn schatten voor zichzelf bewaart en pas na zijn dood van nut is. Deze gedachtegang is voor Cats de aanleiding tot reflectie op de hebzucht en de gehechtheid aan materiële goederen die door het kootspel worden gesymboliseerd. In de tekst dient het dier als metafoor voor een mens die zijn hele leven geld oppot en er zelf geen enkel nut van heeft. ${ }^{51}$ De situatie verandert wanneer de 'centenbijter' sterft:

Maer alsoo haest hy maer en sterft,
Terstont, hy die het groetjen erft,
Die brengt dan lustich aenden dach
Dat eerst geen son of maen sach.

De bezittingen van de oude vrek belanden in de handen van zijn erfgenamen die alles voor hun eigen plezier verteren. De kinderen die op de dood van het dier wachten om met zijn beenderen te kunnen spelen dienen hier als illustratie van de houding van familieleden die op de dood van rijke verwanten rekenen en hun geld en goed hopen over te nemen en te verspillen. De geldzucht betreft dus niet alleen de oude man maar ook zijn hebberige erfgenamen. ${ }^{53}$ Bovendien wordt er

en levert daarmee zijn kritiek op de ijdelheid van wereldse genoegens. Zie Luyken 1977, 47. Het embleem staat op: http://www.dbnl.org/tekst/luyk001desm01_01/luyk001desm01_01_0031.php; geraadpleegd op 18.11.2016.

${ }^{50}$ Cats $1625,\left[\mathrm{I}(*) \mathrm{iiij}^{\mathrm{v}}\right]$.

${ }^{51}$ Cats $1625, \mathrm{I}(* *)^{\mathrm{r}}$.

52 Cats 1625 , I (**) $)^{\mathrm{r}}$.

${ }^{53}$ Een vergelijkbare interpretatie van een geslacht dier biedt een embleem van Jan van der Veen (1578-1659) uit de bundel Zinne-beelden, oft Adams appel (1642) Het embleem 'Na karige spaarige viltige scheerders, Slempers en dempers, en milde verteerders' laat namelijk een geslacht 
een suggestie gewekt dat de verborgen schatten - zowel van het dier alsook van de gierigaard - op een verkeerde manier worden gebruikt. De ossenorganen worden door de kinderen als speelgoed benut en het geld wordt door de begunstigden verkwist. Beide groepen gebruiken het ontvangen bezit dus op geen nuttige wijze en hebben slechts een kortstondige vreugde op het oog.

Zo staan de dieren - wier botten en blazen het spel dienen - en de spelende kinderen voor ondeugden en onedele motieven van de mens. De morele les die hieruit mag worden getrokken kan worden gezien als een bittere waarheid over de menselijke natuur die men vaak niet wil erkennen en die men als dierlijk en onbeschaafd afwijst. Tegelijkertijd is men zich ervan bewust dat dergelijke primitieve gedragingen ook hem niet vreemd zijn. Deze morele wanklank wordt geillustreerd in Cats' gedicht door het gedrag van de kinderen. Het wordt benadrukt dat ze in plaats van nuttige dierorganen die men mag eten, dat wil zeggen vlees en vet, datgene wat 'waardeloos' is kiezen - blazen en kootbenen. Bovendien hebben ze geen aandacht voor de slacht als leersituatie, maar ze zijn geïnteresseerd vooral in het spel. Vanuit dit perspectief lijkt hun handelwijze irrationeel en instinctief ondanks het feit dat ze, net als de volwassenen, van het vlees ook zullen eten. Wat in het gedicht verder niet gezegd wordt, is dat de kinderen door het gebruik maken van het hele dier eigenlijk iets nuttigs doen. De onderdelen die ze benutten worden door anderen niet meer gebruikt. In plaats daarvan wordt er de indruk gewekt dat ze door een kortstondig vermaak worden geleid dat in vergelijking met het 'echt nuttige' volwassenenwerk dwaas en zinloos lijkt.

De kinderen worden hier dus tot dezelfde categoriegroepen als de slachtdieren gerekend: ze zijn even 'natuurlijk', onverstandig en geconcentreerd op het hier en nu. Het enige doel van het leven van vee voor de mens is immers het akkerwerk en dan het slachten en het verkrijgen van vlees. Na de dood van het dier komt er niets want het beest heeft geen ziel. Deze gedachte komt tot volle uitdrukking in Cats' embleem uit de bundel Silenus Alcibiadis, Sive Proteus getiteld 'Quod iuvat exiguum est' (Wat behaagt, is vergankelijk) dat over een oud gebruik van slagersgilden vertelt die één keer per jaar speciaal gekozen slachtdieren door de stad voeren. ${ }^{54}$ De centrale figuur op de embleemprent is een os bestemd voor de slacht (afb. 12). Het dier is met bloemen versierd en wordt op zijn laatste weg door vrolijk spelende muzikanten rondgevoerd en door een slachter met een bijl gevolgd. De weg van de os van zijn stal naar de slachterij fungeert hier als een

varken zien dat in levenden lijve als een vies en nauwelijks nuttig dier wordt beschouwd en pas na de dood wegens de goede smaak van zijn vlees wordt geapprecieerd. Een analoge situatie vindt volgens de dichter plaats na de dood van een rijk en vrekkig familielid dat door zijn verwanten pas wordt gewaardeerd op het moment dat ze zijn zuur gespaarde geld kunnen incasseren. Zie Van der Veen 1642, 70-71. Het embleem staat op: http://www.dbnl.org/tekst/veen010zinn01_01/veen010zinn01_01_0060.php; geraadpleegd op 18.11.2016.

${ }^{54}$ Cats $^{-} 1618$, I.36 [E2 $\left.{ }^{\mathrm{v}}\right]-\mathrm{I} .37$ E3 $^{\mathrm{r}}$, II.38 [E3 $\left.{ }^{\mathrm{v}}\right]-$ II.39 E4 $4^{\mathrm{r}}$, III.38 [E3 $\left.{ }^{\mathrm{v}}\right]-$ III.39 E4 ${ }^{\mathrm{r}}$. Het embleem staat op: http://www.dbnl.org/tekst/cats001sile01_01/cats001sile01_01_0032.php; geraadpleegd op 18.11.2016. 
metaforische illustratie van het menselijk bestaan dat weliswaar plezierig kan zijn maar slechts kort duurt en zeer snel vergaat. Wie zich er niet op tijd van bewust wordt, is net als dit dwaze, met bloemen versierde dier dat helemaal zijn einde niet voelt naderen. ${ }^{55}$ De symbolische duiding van het embleem roept connotaties op met de kinderlijke bezigheden uit het 'Kinder-spel'. De kinderen die zich met kwetsbare en kortstondige ossenblazen vermaken zijn te vergelijken met het dier op weg naar het slachthuis - ze wijden zich aan plezier en vermaak, terwijl het leven snel voorbijgaat en aan het einde een bijl ons allen wacht.

In oppositie tot de kinderen en de dieren zou hier dus een (volwassen) mens staan die zich door zijn rede laat leiden en zich op nuttige werkzaamheden richt. Ook de slachter, die in het 'Kinder-spel' eigenlijk niet wordt genoemd, verheugt zich zeker op de komende slachttijd. Voor hem zou de slacht echter een gelegenheid betekenen om vers vlees te eten en de wintervoorraad aan te leggen. Hiermee wordt gesuggereerd dat de volwassene door geen kortstondige vreugde wordt geleid maar door verdergaande voornemens - het leven hiernamaals. Wat verder opvalt is dat de landbouwdieren en de kinderen als een externe maatstaf voor de volwassen lezer fungeren door middel waarvan hij of zij kan beoordelen hoe 'menselijk' hij of zij zelf is. Door het onderstrepen van de dierlijke, instinctieve natuur van de slachtdieren en de kinderen kan dit zelfbeeld van het volwassen publiek zeker positief uitkomen. Maar zoals we al zagen, verzinnebeeldt het gedicht aan de hand van de kinderspelen en de dierlijke resten ook bepaalde zwakheden van

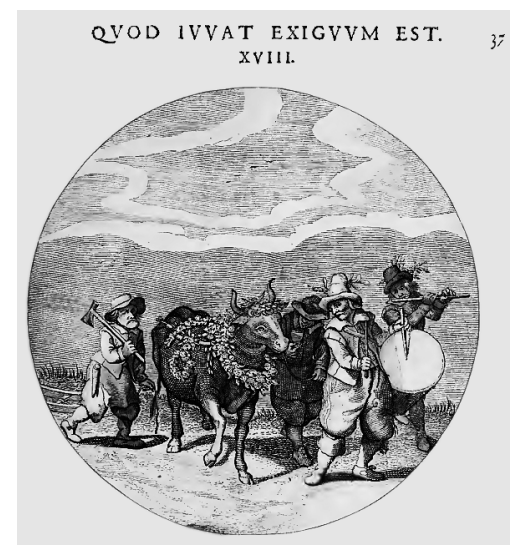

Afb. 12. Os voor de slacht op de embleemprent van Jacob Cats, 'Qvod ivvat exigvvm est', in: Silenus Alcibiadis, Sive Proteus (...). Middelburg 1618, I.37 E3 ${ }^{\text {r }}$ Emblem Project Utrecht, C Publiek Domein

${ }^{55}$ Een amoureuze interpretatie van het motief vinden wij daarentegen in het embleem onder de veelzeggende titel 'Tragedia Amoris' van Ludovicus van Leuven (1600-1661). Het gevaar van verliefdheid wordt ook hier met behulp van de figuur van de os ter slachting getoond. De dichter waarschuwt de lezers voor de kortstondigheid van aardse genoegens en wijst daarnaast op de prijs die men voor de lege pleziertjes zou moeten betalen - de eeuwige nacht. Zie Van Leuven 1629, 80-81. Het embleem staat op: http://emblems.let.uu.nl/ad1629_1_040.html; geraadpleegd op 18.11.2016. 
de volwassen mens. Het wordt duidelijk dat ook diens gedrag soms gevoelsmatig en onverstandig is. De kinderen zijn in Cats' gedicht een waarschuwing voor volwassenen die ook blij zijn om van anderen te profiteren en even veel interesse tonen voor wereldse genoegens als de spelende peuters. Zo is de grens tussen dier en mens en tussen kind en volwassene niet zo vanzelfsprekend. In dit opzicht laten de spelende kinderen en de slachtdieren de mens in zijn onbeschaafde en onzedelijke, dat wil zeggen gedegenereerde vorm zien (degeneratio hominis). ${ }^{56} \mathrm{Ze}$ zijn een beeld van wat er met de mens zonder opvoeding en godsdienst - in het kort zonder cultuur - kan gebeuren.

\section{Tussen geest en materie: wat ons zonder opvoeding bedreigt}

In Cats' gedicht vindt men dus echo's terug van contemporaine pedagogische, theologische en filosofische discussies over natuur en cultuur - de plaats van de mensheid in de natuur en haar niveau van maatschappelijke en zedelijke ontwikkeling. De relatie tussen mens en dier was in dit debat van cruciaal belang. Criteria op basis waarvan de mens zichzelf van het dier onderscheidde, bleven eeuwenlang vrijwel dezelfde: naast de uiterlijke gedaante waren dat zijn rede en de onsterfelijke ziel. Maar het bezitten van het intellect en van het hogere beginsel betekent niet per se dat men zomaar wijs is en de eeuwige zaligheid verwerft. Daartoe moet men opgevoed worden, zowel geestelijk als godsdienstig, want bij de geboorte is men net als 'wilde beesten', schrijft de zeventiende-eeuwse Amsterdamse dominee Petrus Wittewrongel (1609-1662) in zijn gezinspedagogische traktaat Oeconomia Christiana ofte christelicke huys-houdinge (1655). ${ }^{57}$ In de ogen van Wittewrongel zijn kinderen te vergelijken met ongetemde dieren, zoals jonge paarden, die afgericht moeten worden of ook wel met een ongecultiveerd stuk land dat 'wel gebouwet/gemest/ en met goedt saet bezaeyt zijnde wort vruchtbaer/ ende draeght schoone vruchten' ${ }^{58}$ De woorden van de dominee sluiten aan bij het pedagogische discours van calvinistische theologen over de natuurlijke verdorvenheid van de mens. ${ }^{59}$ Zo betoogt de Middelburgse predikant Willem Teellinck (1579-1629)

${ }^{56}$ De degeneratie van de mens werd in de vroegmoderne tijd aanzienlijk vaak door middel van dieren verbeeld, in het bijzonder van de aap. Met de term degeneratio hominis werd bedoeld dat een dier als een negatieve afspiegeling van de mens werd beschouwd. Door het gebrek aan moraal en verstand gold een dier als symbool van menselijke ondeugden en tekortkomingen. Zie hierover: Schepers 2007, 109-113. Over het motief van de aap in de Nederlandse emblemataliteratuur zie de voetnoot verderop.

57 Wittewrongel 1661, 185. Veel aandacht aan Wittewrongels leven, werk en opvoedkundige ideeën besteedt Groenendijk 1978; 1983; 1984(a); 1986, 19, 30, 31, 36; 1987 en 2002, 328.

${ }^{58}$ Wittewrongel 1661, 185.

59 Zie Groenendijk 1984(a), 155-156 en Fila \& Dekker e.a. 2013, 120. 
in zijn Huys-boeck (1618) dat iedereen bij de geboorte zondig is, zelfs de kleinsten:

Sodat even het jonghste kindt/ dat heden aen den dach gheboren is/ niet en is onnoosel [ $=$ onschuldig, JK] ende sonder sonde; al-hoe-wel wy de jonghe kinderkens ghemeynlick onoosele noemen/ ten aensien van de werckelicke sonde/ die sy waerlick niet gedaen hebben/ Rom. 5.14. want andersins soo en zijn sy sonder alle sonde niet/ maer hebben alsou van natueren in sich een sondighe verdorvenheydt (...). ${ }^{60}$

Gezien de aangeboren verdorvenheid van de mens moet hij vanaf de prilste kinderdagen naar godzaligheid geleid worden. Het betekent dat men affecten en 'primitieve' verlangens van kinderen moet onderdrukken, hen in geloofsfundamenten dient te onderwijzen en tot godsdienstige oefeningen aan te sporen. Het concept van de natuurlijke zondigheid van het kind wordt dus gebruikt als rechtvaardiging voor het ouderlijk gezag en voor alle religieuze praktijken met behulp waarvan dit ongecultiveerde 'stuk land' wordt bebouwd.

Het trekken van analogieën tussen de mens, en met name het kind, en verwilderde, ongetemde dieren was echter een al veel eerder bekend motief dat hoogstwaarschijnlijk aan Plutarchus werd ontleend en in de vroegmoderne tijd herhaaldelijk werd gebruikt om negatieve gevolgen van een slechte opvoeding te illustreren. ${ }^{61}$ In de zestiende en zeventiende eeuw ontstonden er tal van variaties op dit motief, niet alleen in opvoedkundige werken maar ook in de literatuur en de schilderkunst. Zo wordt een succesvolle opvoeding geillustreerd aan de hand van gedresseerde dieren - honden en paarden, vinken en sprekende papegaaien - en gecultiveerde planten en bomen alsook verschillende vruchten. Om een slechte opvoeding uit te beelden bediende men zich van allerlei voorbeelden van verwilderde natuur, zoals ongetemde dieren, kromgegroeide bomen, daarnaast ook doornen en distels. Erasmus vergelijkt het kind met een veulen of een hond die men onmiddellijk na de geboorte dient 'voor het gebruik af te richten (...).${ }^{62}$ Cats trekt in zijn Houwelyck een parallel tussen het kind en 'het rouwe lant' dat woest en onbewerkt is. ${ }^{63}$ Hij beweert dat er van een ongecultiveerd land niets anders te verwachten valt dan een snel woekerend onkruid. Maar voor de religieuze vorming van het kind is het 'africhten' van zijn of haar aangeboren natuur echter niet voldoende, stellen zeventiende-eeuwse protestantse moralisten. Ze zijn van mening dat kinderen van jongs af tot godzaligheid aangespoord moeten worden want anders zijn ze net als landbouwdieren die - ofschoon getemd - bij de natuur, dat wil zeggen bij de stoffelijke wereld, horen. ${ }^{64}$ Wie geen plezier in het godsdienstige

${ }^{60}$ Teellinck 1618, 87. Over Willem Teellinck en zijn pedagogische geschriften zie: Hof 1978; Groenendijk 1984 (b); 1986 en 2002, 328.

${ }^{61}$ Zie hierover: Bedaux 2000, 21

62 Erasmus 1992, 78-79.

${ }^{63}$ Cats $1625,58\left[\mathrm{Hhh}^{\mathrm{v}}\right]$.

${ }^{64}$ De nadruk op de vroege catechisatie van de kleinste kinderen was tekenend voor de piëtistische beweging waarvan Wittewrongel en Teellinck tot invloedrijkste vertegenwoordigers worden 
leven zoekt, maar op aardse genoegens blijft focussen, is even 'onverstandich/als muylen en peerden', schrijft Teellinck. ${ }^{65}$ Wittewrongel waarschuwt dat de mens die 'Goddeloos is' en 'geen vermaeck in Godtsdienstighe oeffeninghen' vindt, gelijk een zwijn is dat 'noch geheel vleeschelick, wereldtsch, ende natuerlick is'. ${ }^{66}$

\section{'Wilde kinderen': wie en wat de mens is}

Zo worden kinderen en dieren in bepaalde dimensies van vroegmoderne culturele teksten gezien als vertegenwoordigers van de ongecultiveerde en onbeheerste natuur die door de maatschappij en de cultuur nog moeten worden gevormd. In deze visie worden dieren - zowel wilde als gedomesticeerde - vanuit een strikt antropocentrisch invalshoek beschouwd. Men onderstreept het feit dat ze bij de natuur horen, dat wil zeggen onbezonnen, primitief en werelds zijn, en projecteert op hen deze eigenschappen van de mens die als onbeschaafd en onzedelijk worden geacht. Wat er met de ongeciviliseerde mens gebeurt, komt volledig tot uitdrukking in het fenomeen van zogenaamde 'wilde kinderen'- kinderen die zonder contact met de beschaving en waarschijnlijk met behulp van dieren zijn opgegroeid. Tot de beroemdste gevallen - die de verbeelding van de vroegmoderne mens hebben geprikkeld - behoren het wolfskind uit Hesse (midden veertiende eeuw) en uit de Ardennen (ca. 1500), het berenkind uit Denemarken (ca. 1600) en de jongen Jean van Liège (ca. 1630) ${ }^{67}$ In Cats' Houwelyck vinden we ook zo'n verhaal over een wolfskind dat rondom zijn zevende jaar in een bos wordt gevonden. ${ }^{68}$ De jongen is een menselijk kind maar hij ziet er nauwelijks als een mens uit. Hij spreekt geen menselijke taal; in plaats daarvan uit hij een vreemd geschreeuw. Noch wil hij menselijk voedsel eten, alleen maar bloedig aas. Cats beschrijft zijn uiterlijk als half dier, half mens: 'Sijn wesen is verwoet, en byster onbevreest,/ Het beelt gelijck een mensch, de reste maer een beest' ${ }^{69}$ Het thema 'wilde kinderen' trok de aandacht van veel vroegmoderne historici, moralisten, literatoren en biologen voor wie deze kinderen een ontbrekende schakel tussen het dier en de mens wa-

gerekend. Naar mening van de Piëtisten moest men de kindertijd niet verspillen maar goed gebruiken om kinderen de beginselen van de hervormde religie bij te brengen. Niemand kan immers aan de dood ontsnappen, zelfs de kleinsten. Daarom hoe eerder men met de religieuze vorming begint, des te beter voor de eeuwige zaligheid van het kind. Zie hierover: Spies \& Van Toorn 1990, 144; Groenendijk 1997, 326 en 1984(a), 152-153.

65 Teellinck 1618, 952-953.

${ }^{66}$ Wittewrongel $1661,750$.

${ }^{67}$ Zie hierover: Benzaquén 2006, 280. Tot de bekendste achttiende-eeuwse wilde kinderen behoren Peter van Hannover (ca. 1713-1785) en Marie Angélique Memmie Le Blanc (1712-1775).

Zie: Douthwaite 2002, 21-29 en 29-53; Benzaquén 2006, 73-93 en 93-105.

${ }^{68}$ Cats $1625,51 \mathrm{Ggg}^{\mathrm{r}}-56$ [Ggg4 $\left.{ }^{\mathrm{V}}\right]$.

${ }^{69}$ Cats $1625,52\left[\mathrm{Ggg}^{\mathrm{v}}\right]$. 
ren. ${ }^{70}$ Biologen bedachten voor deze kinderen een nieuwe categorie - homines feri - een intermediair soort tussen mens en dier. Moralisten beweerden daarentegen 'that they inhabited an ambiguous limbo between man and his monstrous, violent ancestors' ${ }^{71}$ Voor beide groepen waren de verhalen over de kinderen echter problematisch - ze riepen vragen op naar de mens en zijn plaats in de natuur. En de vraag hoe de mens in de natuur te situeren was 'the question of all questions', die men door de eeuwen heen probeerde te beantwoorden. ${ }^{72}$

De vroegmoderne belangstelling voor het onderwerp 'wilde kinderen' laat zien dat in het debat over de mensheid en de beschaving kinderen vaak op één lijn met dieren werden gesteld. De verhalen zijn bedoeld om aan te tonen dat zonder opvoeding en leiding van volwassenen civilisatie noch ontwikkeling mogelijk is. Cats stelt dat, hoewel het wolfskind het menselijke wordt geleerd - taal, cultuur, gebruiken - zijn wilde krachten blijkbaar te diep zijn geworteld: op een dag eet hij alle schapen op die hij had leren hoeden. ${ }^{73}$ Ondanks de pogingen om de jongen beschaving, normen en fatsoen bij te brengen blijken zijn natuurdriften en dierlijke verlangens krachtiger. Hij staat te dicht bij de dierenwereld om het hoogste ontwikkelingsniveau - de civilisatie - te bereiken dat aan de 'echte mens' voorbehouden is. De vertellingen demonstreren dus de primitiviteit van de mens zonder opvoeding en beschaving. ${ }^{74}$ Erasmus had al geschreven: 'mensen worden niet geboren, ze worden gemaakt'. ${ }^{75}$ In die visie is de kindertijd een beslissende periode in het menselijk leven wanneer de mens in-between is - ergens tussen dier en mens, natuur en cultuur, materie en geest. Maar aan de andere kant verwoorden de verhalen een diepe angst voor wat er in de mens sluimert, door welke dierlijke driften hij of zij wordt gedreven en waartoe hij of zij in staat is. Gezien de dierlijke natuur van kinderen begint men zich af te vragen wat het mens-zijn in het algemeen betekent. Noemen we onszelf 'mensen' omdat we in biologische zin 'beter' zijn, of 'hoger gesteld' dan andere dieren of omdat we sociale normen en wetten hebben bedacht die de lage instincten in toom houden en ons voor het verwilderen behoeden. Met dergelijke problemen wordt ook de lezer van het 'Kinder-spel' geconfronteerd. De nadruk op de dierlijke natuur van de spelende kinderen geeft de volwassen lezer de plezierige gedachte dat hij of zij zelf geciviliseerd en rationeel is. Maar de symbolische betekenis van de kinderspelen wekt tegelijk angst op omdat men zich realiseert dat men zelf soms even beestachtig handelt en zich eigenlijk niet zo veel van dieren onderscheidt. Zo geeft Cats' gedicht de lezers comfort en neemt het dit tegelijkertijd weg. Om dit onaangename gevoel te doorstaan moet

\footnotetext{
70 Zie herover: Douthwaite 2002, 12.

${ }^{71}$ Douthwaite 2002, 12.

72 Schiebinger 1993, 385.

${ }^{73}$ Cats 1625,56 [Ggg $\left.^{\mathrm{v}}\right]$.

${ }^{74}$ Zie hierover: Douthwaite 2002, 20.

75 Erasmus 1992, 82.
} 
men zich dus mentaal distantiëren van de kinderen en de dieren. De geschiedenis van de dierkunde biedt de mens hier de helpende hand.

Al vanaf de dierenstudie van Aristoteles heeft men anatomische, psychologische en ethologische eigenschappen van dieren onderzocht vanuit kwesties en vragen verbonden met de mens. ${ }^{76}$ Maar terwijl de mens in Aristoteles' zoölogie centraal stond, werd hij in dierenboeken van middeleeuwse scholastici helemaal niet behandeld vanuit de overtuiging dat God 'blessed humans with immortal souls, raising them above brute creation' ${ }^{77}$ In hun optiek behoort de mens dus niet tot het dierenrijk maar staat hij in de goddelijke hiërarchie dichter bij de engelen. Men baseerde zich op het boek Genesis en de idee dat de mens het meesterstuk van de schepping is en heerschappij over alle levende wezens heeft: 'over de vissen der zee, en over het gevogelte des hemels, en over het vee, en over de gehele aarde (...) ${ }^{78}$ Deze paradigmawisseling werd ook op het literaire niveau steeds duidelijker. Het dier begon te fungeren als een metaforische illustratie van menselijke gedragingen. ${ }^{79}$ Aangezien hun gebrek aan rede en moraal werden beesten vaak gebruikt om de aandacht op ondeugden en negatieve eigenschappen van de mens te vestigen. ${ }^{80}$ Dat alles heeft eerst in de middeleeuwen en dan in de Renaissance tot

76 Zie Schiebinger 1993, 385 en Vanpaemel 2007, 51.

77 Schiebinger 1993, 385.

78 Genesis 1:26. [http://www.online-bijbel.nl/bijbelboek/Genesis/1/1-31, geraadpleegd op 31.08.2016].

${ }^{79}$ Dierensymboliek speelt een belangrijke rol in zestiende- en zeventiende-eeuwse embleemboeken. Sommige auteurs, zoals Marcus Gheeraerts (ca. 1520-ca. 1590) en Joost van den Vondel (1587-1679), sluiten aan bij de middeleeuwse fabeltraditie en trekken een morele les uit het gedrag van dieren die zich half menselijk en half dierlijk opstellen. Bovendien behoren dieren tot een vaste canon van de zogenaamde 'realistische' emblemata waarin alledaagse situaties en onderwerpen centraal staan. Het gedrag van verschillende beesten - honden en katten, muizen en vogels, insecten en paarden, maar ook exotische en fabelachtige wezens - wordt door auteurs, als Cats, Roemer Visscher (1547-1620), Johan De Brune de Oude (1588-1658) en Jan Luyken, als afspiegeling van menselijke zaken en handelingen gebruikt. Over de fabeltraditie en dierenemblemen zie: Koppenol 2007, 453-460; Over de realistische emblemataliteratuur zie bijvoorbeeld: Porteman 1977, $117-$ 139; Zie over dieren in emblemen van Cats: Luijten 1996, dl. 2, 29-31, 35 en van Visscher: Brummel 1949, xxxii-xxxiv.

${ }^{80}$ Naast slachtdieren waren het onder andere apen en katten die als afspiegelingen van negatieve gedragingen vaak werden gebruikt. In het embleem van Jan Luyken 'De Aap' (1977, 267-269) uit zijn Beschouwing der wereld (1708) fungeert het dier als illustratie van de zondige mens die zich door zinnelijke zaken laat verlokken en voor het innerlijke leven geen interesse heeft. Het embleem staat op: http://www.dbnl.org/tekst/luyk001besc01_01/luyk001besc01_01_0068.php; geraadpleegd op 20.11.2016. Tot geliefde thema's van de Nederlandse emblematiek behoort bovendien het motief van de moederaap die uit blinde liefde haar kind doodperst. Het onderwerp komt onder meer voor in Vondels 'De Aep met haer Ionghen' (1927, 526-527) uit zijn Vorsteliicke Warande der dieren (1617) waar het dier voor de onverstandige ouderliefde staat en in Ludovicus van Leuvens 'Censura Amoris' $(1629,22-23)$ uit de bundel Amoris Divini et hvmani antipathia waar de aap ter illustratie van een vrijer dient die door de liefde blind is gemaakt en gebreken van zijn minnares niet ziet. De emblemen staan respectievelijk op: http://www.dbnl.org/tekst/vond001dewe01_01/vond001de- 
een fundamenteel onderscheid tussen mens en dier geleid. De gedachte dat mensen een onsterfelijke ziel bezitten werd door protestantse theologen verder ontwikkeld om de gelovige christen - de ware mens - van deze ongelovige - het vleselijke en natuurlijke dier - te onderscheiden. De ontwikkelingen van de vroegmoderne natuurwetenschap en de intensieve stroom van nieuwe informatie verworven door ontdekkingsreizen hebben het geloof aan deze superieure positie van de mens op losse schroeven gezet. De mens werd gedwongen om zijn positie voortdurend te herdefiniëren 'and, of course, nonhuman animals were the first line of attack', merkt Simon C. Estok op. ${ }^{81}$ Zo droeg de middeleeuwse theologie bij aan het ontstaan van verschillende, stereotiepe beelden over dieren wat de maatschappelijke concepten rondom deze wezens langdurig heeft beïnvloed. Om er een paar te noemen:

Dieren waren wild, gewelddadig, onbezonnen, irrationeel, of - anders gezegd - geheel tegengesteld aan de mens. Dieren werden niet door de rede, maar door het instinct gedreven.

we01_01_0110.php en http://emblems.let.uu.nl/ad1629_1_011.html; geraadpleegd op 20.11.2016.

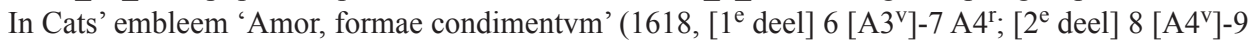
$\mathrm{B}^{\mathrm{r}}$; [ $3^{\mathrm{e}}$ deel] 8 [A4 $\left.{ }^{\mathrm{v}}\right]-9 \mathrm{~B}^{\mathrm{r}}$ ) uit de bundel Silenus Alcibiadis krijgt het onderwerp drie verschillende betekenissen. Eerst treedt het dier als metafoor voor de blinde liefde, dan voor de vererving van goede en slechte eigenschappen van de ouders en ten slotte wordt de moederaap positief voorgesteld en symboliseert zij de christelijke naastenliefde. Het embleem staat op: http://emblems.let.uu.nl/ c161803.html; geraadpleegd op 20.11.2016. De kat treedt onder andere op in emblemata van Roemer Visscher en Cats. Een kandelaar likkende kat staat in Visschers 'Elck zijn waerom' $(1949,70)$ uit de bundel Sinnepoppen (1614) voor mensen met verschillende beroepen voor wie het geld de grootste motivatie is om hun verplichtingen te vervullen. Het embleem staat op: http://www.dbnl. org/tekst/viss004sinn01_01/viss004sinn01_01_0073.php; geraadpleegd op 20.11.2016. Het motief komt terug in Cats' 'Om de minne van het smeer, leckt de kat den kandeleer' $(1862,713-714)$ uit het emblemataboek Spiegel van den ouden ende nieuwen tijdt (1632) waarin het gedrag van de kat met de handelwijze van een man vergeleken wordt die om materiële redenen met de minst aantrekkelijke vrouw in de hele buurt beslist te trouwen. Het embleem staat op: http://www.dbnl.org/ tekst/cats001jvan02_01/cats001jvan02_01_0326.php; geraadpleegd op 20.11.2016. Het dient echter opgemerkt te worden dat dieren uit veel Nederlandse embleemverzamelingen ook positieve zaken en handelingen verbeelden. De rups, die haar gedaante verwisselt en als vlinder tevoorschijn komt, is bijvoorbeeld een beest dat uiterst vaak een positieve interpretatie krijgt. De vlinderlarve geldt meestal als metafoor voor de wedergeboorte en het eeuwige leven. In de religieuze interpretatie van Cats' embleem 'Amor elegantiae pater' (1627, 308-315) uit de bundel Proteus ofte Minne-beelden verandert in Sinne-beelden staat de vlinder, die uit zijn cocon tevoorschijn is gekomen, voor de herrijzenis van de godvruchtige christen. Het embleem staat op: http:/emblems.let.uu.nl/c162752. html; geraadpleegd op 20.11.2016. In Jan Luykens embleem 'De ryp' (1711, 50-53) uit de bundel De bykorf des gemoeds (1711) fungeert de rups als symbool van de gelovige die zich na de dood van het aardse losmaakt en in Christus herboren wordt. Het embleem staat op: https://books.google.pl/ books?id=eIxFAAAAcAAJ\&printsec $=$ frontcover\&hl $=$ pl\&source $=$ gbs_ge_summary_r $\&$ cad $=0 \# \mathrm{v}=$ onepage\&q\&f=false; geraadpleegd op 20.11.2016. Over het motief van de aap zie: Schepers 2007, 109-113 en in het bijzonder over de moederaap zie: Luijten \& Blankman 1996, 20-21 en Luijten 1996, dl. 2, 198-200. Over het motief van de rups zie: Luijten \& Blankman 1996, 29-31 en Luijten 1996, dl. 2, 763-766.

${ }^{81}$ Estok 2007, 69. 
Zij waren niet geschapen naar Gods gelijkenis, en zouden niet met de mens verrijzen. In dit perspectief werden dieren louter beschouwd als eigendom, voedsel of jachtprooi. ${ }^{82}$

Deze laatste zin geldt voor dieren in het algemeen maar voor slachtdieren in het bijzonder. In hun geval wordt er vaak benadrukt dat ze voor consumptie bestemd zijn. Terwijl de natuurlijke bestemming van de mensheid de hoop op het eeuwige leven is, is het in geval van vetweiders het slachthuis en het leveren van vlees. Hetzelfde geldt eveneens voor kinderen die volgens de protestantse auteurs bij hun geboorte zondig zijn en waarschijnlijk ook voor de 'wilde kinderen'. Dankzij een goede opvoeding krijgen kinderen kans op het eeuwig heil. In de christelijke visie kunnen dieren daar absoluut niet op rekenen.

\section{'Blind spot': wat wij niet (willen) zien}

Het valt op dat de stereotiepe denkschema's over dieren en de afstand tussen mens en dier aan de ene kant bedoeld zijn om de mens permanent van de dierenwereld te onderscheiden en aan de andere kant om zijn heerschappij over en exploitatie van beesten te verantwoorden. Volgens Homi K. Bhabha, een van de belangrijkste onderzoekers op het gebied van postkoloniale kritiek, fungeren stereotiepe beelden over gekoloniseerde gemeenschappen als rechtvaardiging voor hun verovering en uitbuiting. ${ }^{83}$ Het mechanisme roept connotaties op met een hier besproken machtsrelatie tussen mens en dier waarbij het culturele beeld van het dier dient om de superieure positie van de mens te behouden en zijn wanpraktijken te legitimeren. Mijns inziens is het bestempelen van beesten als instinctief en onverstandig echter niet voldoende om hen als voedsel of jachtprooi te behandelen. Om een dier werkelijk te eten moet je de oorsprong van je voedsel irreëel maken alsof er tussen het slachthuis en je bord een soort 'blind spot' zou zijn. Zoals Simon C. Estok terecht opmerkt: 'If we are to eat flesh, such conceptual distancing is necessary. It is precisely in reducing the conceptual distance between "animal as animal" and "animal as food" (...) ${ }^{84}$

Zo'n conceptuele afstand vinden wij ook in het gedicht van Cats terug, met name op het niveau van de taal. De os wordt hier vlak voor de dood gepresenteerd en direct na de slacht 'verandert' het dier in: 'osse-vleys', 'innich been', 'het smeir', 'het roet', 'gevoet', 'blaes' en 'koot' ${ }^{85}$ Zo scheppen lexicale formu-

82 Vanpaemel 2007, 52. In het debat van middeleeuwse, christelijke theologen wordt een algemeen beeld over het dier gehanteerd, dat wil zeggen zonder onderscheiding van zijn soort of domesticatiegraad.

83 Bhabha 2010, 62-63.

${ }^{84}$ Estok 2007, 75.

${ }^{85}$ Cats 1625 , [I $\left(^{*}\right)$ iiij $\left.^{\mathrm{V}}\right]$ en I $(* *)^{\mathrm{r}}$. Hetzelfde geldt ook voor de onderdelen van de os waarmee wordt gespeeld. Het dier is niet meer een beest, maar 'verandert' in speelgoed, dat wil zeggen in kootjes en luchtballonen. 
leringen distantie tussen de mens en de landbouwdieren en hun leed. ${ }^{86}$ Hetzelfde gebeurt ook vandaag: 'we eat beef, not bull (...) and pork, not pig (...), a carcass, not a corpse' ${ }^{87}$ De taal waarmee de mens met het vlees omgaat is tekenend voor de postmoderne afstand tot de herkomst van ons voedsel: '(...) more than a third of young adults in Britain don't know that bacon comes from a pig, milk from a cow or eggs from a hen', lezen wij in het wereldberoemde boek Farmageddon. The True Cost of a Cheap Meat (2014) van de activisten voor het dierenwelzijn - Philip Lymbery en Isabel Oakeshott. ${ }^{88}$ De mechanismen van vervreemding die al in Cats' gedicht aan het licht komen, zijn dus ook aanwezig in de tegenwoordige manier van het denken. Het is bovendien opmerkelijk dat een dergelijke denkbeeldige distantiëring ons niet alleen helpt om de exploitatie van dieren psychologisch te verantwoorden, maar het werkt ook de hedendaagse agro-productie in de hand, in het bijzonder de intensieve veehouderij. Het houden van vee voor eigen consumptie is in de loop der tijd vervangen door grootschalige en steeds meer gemechaniseerde veebedrijven. Het productieproces is vandaag zo georganiseerd dat wij eigenlijk geen kans hebben om met de, nog levende, dieren in contact te komen en hun echte levensomstandigheden met eigen ogen te zien. ${ }^{89}$ Een publiek geheim is dat varkens en koeien in megastallen benauwd weggestopt zijn waardoor ze vaak op elkaars dode lichamen staan. Ze worden vetgemest en volgepropt met antibiotica en groeihormonen om de vlees- en melkproductie steeds efficiënter te maken. Kuikens worden op de lopende band gesekst en eieren snel afgevoerd. Efficiëntie, schaalvergroting en specialisatie zijn factoren die de hedendaagse vleesproductie domineren. ${ }^{90} \mathrm{Wij}$ zijn tegenwoordig zo vervreemd van de dieren, hun leven en dood, dat de aanwezigheid van kinderen in een slagerij en het vervaardigen van speelgoed van dierlijke resten waarover wij in Cats' gedicht lezen vandaag moeilijk voorstelbaar zouden zijn. Stukken vlees die wij in supermarkten vinden, zijn in mooie porties vacuüm verpakt 'giving no sense of the animals from which the flesh came' of wat er achter de staldeur werkelijk gebeurt. ${ }^{91}$

In het licht van de bovenstaande overwegingen is het niet verwonderlijk dat de foto's van het meisje met het warme, bebloede hertenhart in haar mond zo veel controverses hebben gewekt. Voor mensen van nu kan een dergelijk beeld inderdaad schokkend zijn. De reactie kan echter niet alleen esthetische walging zijn maar ook ethische twijfel: waar is nou precies de mens in dit verhaal en waar het dier. Het opeten van het rauwe hertenhart lijkt een heel letterlijk teken van de macht die het

${ }^{86}$ Zie over verschillende praktijken op het niveau van de taal die ons afstand van de herkomst van ons voedsel laten scheppen: Stibbe 2001.

87 Stibbe 2001, 150.

${ }^{88}$ Lymbery \& Oakeshott 2014, 10.

89 Over de hedendaagse vleesproductie zie bijvoorbeeld: Jonge \& Goewie 2000; Lymbery \& Oakeshott 2014; Fresco 2015.

${ }^{90}$ Zie Jonge \& Goewie 2000, 7-8.

${ }^{91}$ Estok 2007, 75. 
meisje over het door haar gedode dier uitoefent. Zulk gedrag doet denken aan iets instinctiefs en dierlijks. Opvallend is dat ook de lezer van Jacob Cats' 'Kinder-spel' met een dergelijke indruk wordt geconfronteerd. De os wiens organen onmiddellijk na de slacht door volwassenen en kinderen worden benut, wordt op het symbolische niveau met de oude man vergeleken wiens vermogen na de dood door verwanten wordt overgenomen en verkwist. Toegegeven moet worden dat de parallel wel krachtig is en de verbeelding wakker roept waarbij figuren uit beide registers gecombineerd worden. De os wordt hier in de rijke grijsaard 'veranderd' en is nu door zijn erfgenamen 'geconsumeerd' ofwel met de woorden van Cats: 'ruyterlijck verteert' ${ }^{92}$ Wat wij zien is dus tegelijk het dier en de mens die objecten zijn van eenzelfde 'maaltijd'. Op deze manier wordt de lezer zijn veiligheidsgevoel ontnomen dat door de psychologische distantiëring van mens en dier tot stand was gebracht. Het wordt duidelijk dat dier mens is en mens - dier en vanaf dit moment is het eten van het ene of het andere niet meer verantwoord. De 'blind spot' tussen het levende wezen en het vlees op iemands bord wordt hiermee opgevuld. De gedachte die zich dan meteen aandient wordt mijns inziens treffend geformuleerd door de ecocriticus Simon C. Estok voor wie het actieve lezen van Shakespeare's toneelstukken zonder vragen te stellen naar de aanwezigheid van het vlees in het spel niet kan: 'The question (...) is simple: from an ethical perspective, how do we dare sit down to the table to eat animals? This is radical and subversive drama at its best ${ }^{93}$ Door de kannibalistische scène wordt de individuele mens-dierrelatie, die door verschillende bovengenoemde sociale en culturele praktijken verloren ging, in Cats' gedicht weer opgeroepen wat onze postmoderne manier van het denken en ons eigen zelfbeeld als 'de mensen' in twijfel trekt. Wij worden gewaar dat wij in werkelijkheid dieren zijn en dat dit feit niet te ontkennen is. Het wordt duidelijk dat het definiëren van de mens in oppositie tot het dier tot degeneratie en extreem exploiteren van de natuur - inclusief dieren - leidt; met andere worden: tot gedragingen die noch humanitair noch moreel verantwoord zijn. Door dieren te eten en de grootschalige vee-industrie te scheppen die voornamelijk door efficiëntie wordt gedreven en met dierenwelzijn geen rekening houdt, handelen wij als de hebberige familieleden uit het 'Kinderspel' van Cats. De mens die door zijn consumptievoorkeuren de intensieve veehouderij steunt geeft zijn toestemming aan het dierenleed en verspeelt het recht om over menselijkheid en civilisatie te spreken.

\section{Tot slot}

De vraag naar de relevantie van wetenschappelijk werk, met name van literatuurstudies, is een kwestie waarvoor onderzoekers steeds vaker worden gesteld. Door de dalende belangstelling van studenten voor de historische letterkunde moeten de we-

\footnotetext{
92 Cats 1618, $108\left[\mathrm{O}^{\mathrm{v}}\right]$.

93 Estok 2007, 67.
} 
tenschappers naar nieuwe wegen en ruimtes gaan zoeken door middel waarvan hun werk op academisch en maatschappelijk niveau kan worden gelegitimeerd, besluit Jürgen Pieters in zijn Historische letterkunde vandaag en morgen. ${ }^{94}$ De methodes aangeboden enerzijds door de ecokritiek en anderzijds door het New Historicism, en in het bijzonder hun nadruk op de actualiteit van de historische analyses, lijken mij een goede manier om het belang van het wetenschappelijke tekstonderzoek aan te tonen. In dit artikel heb ik geprobeerd hedendaagse maatschappelijke constructen van landbouwdieren ter discussie te stellen via het vroegmoderne debat over de mens en zijn relatie tot het dierenrijk. Uit de bespreking van het gedicht 'Kinderspel' van Jacob Cats is gebleken dat deze verhouding hiërarchisch is en gegrond wordt op de relatie tussen volwassene en kind. Interessant is dat, terwijl het gevoelsmatige en irrationele gedrag van de spelende kinderen een link schept tussen mensen en dieren, de rede - een kenmerk tekenend voor volwassenen - hen van de dierenwereld dient te onderscheiden. Het kind fungeert hier dus als figuur die zowel menselijke als dierlijke aspecten in zich draagt en het hangt van de opvoeding af, of van het gebrek daaraan, in welke richting het zich ontwikkelt. Dat alles stelt kinderen bloot aan het gezag van volwassenen en hun pogingen om dit 'rouwe lant' te cultiveren. Maar Cats' gedicht werpt bovendien licht op het collectieve denken over de menselijke superioriteit boven dieren en de daaruit voortvloeiende legitimatie van hun uitbuiting. Net als het verhaal over het jagende meisje brengt het 'Kinder-spel' de lezers uit hun mentale evenwicht, wat niet alleen de ontwikkeling van zekere denkschema's laat zien maar ook hun juistheid en vanzelfsprekendheid aan het wankelen brengt. Alle pogingen, die mensen in het werk stellen om zichzelf in oppositie tot dieren te definiëren en om hun heerschappij over de natuur te rechtvaardigen, worden dankzij deze momenten van het 'verbroken evenwicht' betwijfeld. De filosofische, theologische en biologische vraag wat de mens betekent en wie de mens is, wordt op die manier verplaatst van het niveau van wetenschappelijke discussies naar het niveau van ons eigen bord en onze voedingspatronen. De vraag rijst: hoe kunnen wij onszelf 'mensen' noemen terwijl wij dieren eten? In zijn symbolische dimensie toont het kinderspel met dierlijke resten dus aan dat de manier waarop wij met dieren omgaan een afspiegeling is van onze eigen, menselijke conditie.

\section{Bibliografie}

\section{Primaire literatuur}

Cats, Jacob, Alle de werken, Deel 2. J. van Vloten (ed.). Zwolle 1862.

Cats, Jacob, Hovwelyck. Dat is De gansche gelegentheyt des Echten Staets. Middelburg 1625. [Universiteitsbibliotheek Vrije Universiteit Amsterdam, sign. XH.00117].

94 Pieters 2011, 88-89. 
Cats, Jacob, Proteus ofte Minne-beelden verandert in Sinne-beelden. Rotterdam 1627. [Online: http://emblems.let.uu.nl/c1627.html (20.11.2016)].

Cats, Jacob, Silenus Alcibiadis, Sive Proteus, Vitae humanae ideam, Emblemate trifariàm variato, oculis subijciens. Deus nobis haec otia fecit. Middelburg 1618. [Universiteitsbibliotheek Vrije Universiteit Amsterdam, sign. XH.00091].

Erasmus, 'Traktaat over opvoeding en onderwijs', in: Erasmus, Over opvoeding en vrije wil. Ed. Jan Sperna Weiland. Baarn 1992, 77-117.

Leuven, Ludovicus van, Amoris Divini et Hvmani Antipathia (...). Antwerpen 1629. [Online: http:// emblems.let.uu.nl/ad1629_1_040.html (30.08.2016)].

Luyken, Jan, Beschouwing der wereld. Utrecht 1977.

Luyken, Jan, De Bykorf des Gemoeds, Honing zaamelende uit allerly Bloemen (...). Amsterdam 1711. [Online: https://books.google.pl/books?id=eIxFAAAAcAAJ\&hl=pl\&source=gbs navlinks_s (20.11.2016)].

Luyken, Jan, Des menschen begin, midden en einde. P. Arentz \& K. vander Sys (eds.). Utrecht 1977.

Teellinck, Willem, Huys-boecxken, ofte Eenvoudighe verclaringhe ende toe-eygheninghe/ van de voornaemste vraegh-stucken des Nederlandtschen Catechismi. Middelburg 1618. [Online: https://books.google.pl/books?id=ylxkAAAAcAAJ\&dq=huys-boecxken\&hl=pl\&pg=PP5\#v=o nepage $\& \mathrm{q}=$ huys-boecxken $\& \mathrm{f}=$ false $(30.08 .2016)]$.

Veen, Jan van der, Zinne-beelden, oft Adams appel. Amsterdam 1642. [Online: http://www.dbnl.org/ tekst/veen010zinn01_01/veen010zinn01_01_0060.php (30.08.2016)].

Visscher, Roemer, Sinnepoppen. L. Brummel (ed.). Den Haag 1949.

Vondel, Joost van den, De werken van Vondel. Eerste deel 1605-1620. J.F.M. Sterck, H.W.E. Moller e.a. (eds.). Amsterdam 1927.

Wittewrongel, Petrus, Oeconomia Christiana ofte Christelicke Huys-houdinghe. Vervat in Twee Boecken. Amsterdam 1661. [Online: https://books.google.pl/books?id=2_RjAAAAcAAJ\&hl $=$ pl\&pg $=$ PP7\# $=$ onepage \&q \&f=false $(30.08 .2016)]$.

\section{Secundaire literatuur}

Bedaux, Jan Baptist, 'Inleiding', in: Jan Baptist Bedaux \& Rudi Ekkart (red.), Kinderen op hun mooist. Het kinderportret in de Nederlanden 1500-1700. Gent/Amsterdam 2000, 11-32.

Benzaquén, Adriana S., Encounters with Wild Children. Temptation and Disappointment in the Study of Human Nature. Montreal 2006.

Berge, Domien ten, De hooggeleerde en zoetvloeiende dichter Jacob Cats. 's-Gravenhage 1979.

Bertens, Hans, Literary Theory. The Basics. London/New York 2014.

Bhabha, Homi K., Miejsca Kultury. Tomasz Dobrogoszcz (vert.). Kraków 2010.

Bruckner, Lynne \& Dan Brayton (eds.), Ecocritical Shakespeare. London/New York 2016.

Brummel, L., 'Inleiding', in: Roemer Visscher, Sinnepoppen. L. Brummel (ed.). Den Haag 1949, vii-Xxxv.

Devisscher, Frans (red.), Wonderlycke dieren op papier in de tijd van Plantin. Antwerpen 2007.

Douthwaite, Julia V., The Wild Girl, Natural Man and the Monster. Dangerous Experiments in the Age of Enlightenment. Chicago/London 2002.

Drost, Johanna Wilhelmina Petronella, Het Nederlandsch kinderspel vóór de zeventiende eeuw. 'sGravenhage 1914.

Estok, Simon C., 'Afterword: Ecocriticism on the Lip of a Lion', in: Lynne Bruckner \& Dan Brayton (eds.), Ecocritical Shakespeare. London/New York 2016, 239-246.

Estok, Simon C., 'Theory from the Fringes: Animals, Ecorticism, Shakespeare', Mosaic 40/1 (2007), 61-78.

Neerlandica Wratislaviensia 26, 2016

(C) for this edition by CNS 
Fila, Jack \& Jeroen J.H Dekker e.a. (red.), De kunst van het opvoeden. Zutphen 2013.

Fraipont, Barbara, "'[H] et dier in al zijn toonaarden" - Over zoöpoeticale configuraties in Charlotte Mutsaers' beeldend en literair werk', Nederlandse Letterkunde 19/1 (2014), 67-87.

Fresco, Louise O., Hamburgers in Paradise. The Stories Behind the Food We Eat. Princeton 2015. Gallagher, Catherine \& Stephen Greenblatt. 'The Mousetrap', in: Catherine Gallagher \& Stephen Greenblatt, Practicing New Historicism. Chicago 2000, 136-162.

Glotfelty, Cheryll, 'Introduction: Literary Studies in an Age of Environmental Crisis', in: Cheryll Glotfelty \& Harold Fromm (eds.), The Ecocriticism Reader. Landmarks in Literary Ecology. Athens 1996, xv-xxxvii.

Greenblatt, Stephen, 'Kultura', vert. Anna Rajca-Salata, in: Stephen Greenblatt, Poetyka Kulturowa. Pisma Wybrane. Kraków 2006,145-156.

Groenendijk, Leendert F., De Nadere Reformatie van het gezin. De visie van Petrus Wittewrongel op de christelijke huishouding. Dordrecht 1984(a).

Groenendijk, Leendert F., 'Een kinderboek uit de Gouden Eeuw: de 'euthanasie' van Susanna en Jacob Bickes. Bijdrage tot de kennis van het kind en de kinderliteratuur in de geschiedenis van het Nederlandse gereformeerde Piëtisme', Nederlands tijdschrift voor opvoeding, vorming en onderwijs 13 (1997), 316-331.

Groenendijk, Leendert F., 'Gezin en opvoeding in dienst van de theocratie bij Petrus Wittewrongel', Theologia reformata 26 (1983), 290-305.

Groenendijk, Leendert F., 'Inhoud en oorsprong van de opvoedingsleer van Petrus Wittewrongel', Documentatieblad Nadere Reformatie 2/1 (1978), 13-28.

Groenendijk, Leendert F., 'Opdat de mensche Godts volmaeckt zy. Lectuur voor de religieuze vorming der gereformeerden tijdens de zeventiende eeuw, met bijzondere aandacht voor de bijdrage van de Nadere Reformatie aan de gezinsdevotie- en catechisatie', Pedagogische verhandelingen 9/2 (1986), 16-54.

Groenendijk, Leendert F., 'Petrus Wittewrongel', in: T. Brienen e.a. (eds.), Figuren en thema's van de Nadere Reformatie. Kampen 1987, 64-70.

Groenendijk, Leendert F., 'Piëtistische opvoedingsleer in Nederland. Balans van een kwarteeuw historisch-pedagogisch onderzoek', Pedagogiek 22/4 (2002), 326-337.

Groenendijk, Leendert F., 'Willem Teellinck over de gezinsreformatie', Documentatieblad Nadere Reformatie 8/2 (1984(b)), 41-51.

Hallema, Anne \& J.D. van der Weide, Kinderspelen voorheen en thans inzonderheid in Nederland. 's-Gravenhage 1943.

Hindman, Sandra, 'Pieter Bruegel's Children's Games, Folly, and Chance', The Art Bulletin 63/3 (1981), 447-475.

Hof, W.J. op 't, 'Willem Teellinck in het licht zijner geschriften (8)', Documentatieblad Nadere Reformatie 2/4 (1978), 97-105.

Jonge, H. de \& Eric A. Goewie, In het belang van het dier. Over het welzijn van dieren in de veehouderij. Assen 2000.

Koppenol, Johan, 'Noah's Ark Disembarked in Holland: Animals in Dutch Poetry, 1550-1700', in: Karl E.A. Enenkel \& Paul J. Smith (eds.), Early Modern Zoology. The Construction of Animals in Science, Literature and the Visual Arts. Leiden/Boston 2007, 451-528.

Kozikowska, Joanna, 'Ex nugis seria: een vergelijkende analyse van twee versies van het gedicht 'Kinder-spel' (1618/1625) van Jacob Cats', in: Wilken Engelbrecht \& Bas Hamers (eds.), Over de grens bekeken. Transmissie van de cultuur van de Lage Landen. Olomouc 2016, 109-132.

Kozikowska, Joanna, 'Teksten in contexten of voorstellingen van kinderen in Jacob Cats' Houwelyck en de anonieme Der Vroed-vrouwen verre-kyker', Neerlandica Wratilsaviensia XX (2011), 55-74.

Kusters, Wiel, Koolhaas'dieren. Over de biologie van een schrijver. Nijmegen 2008. 
Luijten, Hans, Jacob Cats. Sinne- en minnebeelden. 3 dln. Den Haag 1996.

Luijten, Hans \& Marijke Blankman (eds.), Minne- en zinne-beelden. Een bloemlezing uit de Nederlandse emblematiek. Amsterdam 1996.

Lymbery, Philip \& Isabel Oakeshott, Farmageddon. The True Cost of Cheap Meat. London 2014.

Meertens, P.J., Letterkundig leven in Zeeland in de zestiende en de eerste helft der zeventiende eeuw. Amsterdam 1943.

Orrock, Amy, Play and Learning in Pieter Bruegel's Children's Games. Doctoraalscriptie University of Edinburgh, 2010.

Pieters, Jürgen, Historische letterkunde vandaag en morgen. Amsterdam 2011.

Pieters, Jürgen, 'In denkbeeldige tegenwoordigheid: Naar een New Historicism in de Lage Landen?', Spiegel der Letteren 47/3 (2005), 251-271.

Pieters, Jürgen, Moments of Negotiation. The New Historicism of Stephen Greenblatt. Amsterdam 2001.

Pluis, Jan, Kinderspelen op tegels. Assen 1979.

Porteman, Karel \& Mieke B. Smits-Veldt, Een nieuw vaderland voor de muzen. Geschiedenis van de Nederlandse literatuur 1560-1700. Amsterdam 2008.

Porteman, Karel, Inleiding tot de Nederlandse emblemataliteratuur. Groningen 1977.

Schepers, Bert, 'Aepen, simmekens, bevejanen en mertecooien. De aanwezigheid en symbolische betekenis van de aap in de maatschappij en beeldcultuur van de Lage Landen, 1500-1700', in: Frans Devisscher (red.), Wonderlycke dieren op papier in de tijd van Plantin. Antwerpen 2007, 95-123.

Schiebinger, Londa, 'Why Mammals are Called Mammals: Gender Politics in Eighteenth-Century Natural History', The American Historical Review 98/2 (1993), 382-411.

Sedláčková, Lucie, 'Ecologische thematiek in hedendaagse fictie: Uitdagingen van milieufilosofie, ecocritiek en animal studies voor de Nederlandstalige literatuur', Werkwinkel 10/1 (2015), 99-114.

Skrobut, Joanna, 'Het kind als literair motief en sociaal-cultureel verschijnsel in de Nederlandse zeventiende-eeuwse literatuur', in: Wilken Engelbrecht \& Bas Hamers (red.), Neerlandistische ontmoetingen: Trefpunt Olomouc. Olomouc 2010, 25-33.

Sneller, Agnes A. \& Boukje Thijs, 'Nawoord', in: Jacob Cats, Huwelijk. A. Agnes Sneller \& Boukje Thijs (eds.). Amsterdam 1993, 137-153.

Spies, Marijke \& Annemarie van Toorn, 'Christen Jeugd, leerd Konst en Deugd. De zeventiende eeuw', in: Nettie Heimeriks \& Willem van Toorn (red.), De hele Bibelebontse berg. De geschiedenis van het kinderboek in Nederland en Vlaanderen van de middeleeuwen tot heden. Amsterdam 1990, 105-167.

Stibbe, Arran, 'Language, Power and the Social Construction of Animals', Society \& Animals 9/2 (2001), 145-161.

Vanpaemel, Geert, 'Wonderlijk, exotisch en vreemd. Dierenboeken in de vroegmoderne wetenschap', in: Frans Devisscher (red.), Wonderlycke dieren op papier in de tijd van Plantin. Antwerpen 2007, 49-60.

Veeser, Harold Aram, 'Introduction', in: Harold Aram Veeser (ed.), The New Historicism. New York/London 1989, IX-XVI.

Verheyen, Rudi, 'Epiloog: behoud van biodiversiteit', in: Frans Devisscher (red.), Wonderlycke dieren op papier in de tijd van Plantin. Antwerpen 2007, 125-137.

Willemsen, Annemarieke, Kinder delijt. Middeleeuws speelgoed in de Nederlanden. Nijmegen 1998.

Willemsen, Annemarieke, 'Speelgoed als spiegel van middeleeuws kinderleven', in: Pieter Stokvis (red.), Geschiedenis van het Privéleven. Bronnen en benaderingen. Amsterdam/Heerlen 2007, 233-261.

Neerlandica Wratislaviensia 26, 2016

(C) for this edition by CNS 
Willemsen, Annemarieke, 'The Game of the Month. Playful Calendars in Ghent-Bruges Books of Hours', in: Brigitte Dekeyzer \& Jan van der Stock (eds.), Manuscripts in Transition: Recycling Manuscripts, Texts and Images. Leuven 2005, 419-430

Winkel, Jan te, De ontwikkelingsgang der Nederlandsche letterkunde III. Geschiedenis der Nederlandsche Letterkunde van de Republiek der Vereenigde Nederlanden (1). Haarlem 1923.

\section{Webpagina's}

Digitale Bibliotheek voor de Nederlandse Letteren, http://www.dbnl.org/ (20.11.2016).

Emblem Project Utrecht, http://emblems.let.uu.nl/ (08.12.2016).

Genesis 1:26, http://www.online-bijbel.n1/bijbelboek/Genesis/1/1-31 (31.08.2016).

Hauwermeiren, Arno van, Vader laat dochtertje (8) rauw hart opeten van hert dat ze net heeft doodgeschoten, http://www.hln.be/hln/nl/960/Buitenland/article/detail/2839023/2016/08/24/ Vader-laat-dochtertje-8-rauw-hart-opeten-van-hert-dat-ze-net-heeft-doodgeschoten.dhtml (29.08.2016).

Internet Archive, https://archive.org/ (12.03.2017).

Ośmiolatka gryzie "cieple, drżace serce" upolowanego jelenia. Myśliwi: to stara tradycja, http:// wyborcza.pl/1,75399,20606095,osmiolatka-gryzie-cieple-drzace-serce-upolowanego-jelenia. html (29.08.2016).

Prater, Danny, 8-Year-Old Girl Bites Into the Heart of a Deer She Shot for Fun, http://www.peta.org/ blog/girl-bites-raw-dead-deer-heart-new-zealand-hunting-post/ (29.08.2016).

Rijksmuseum Amsterdam, http://rijksmuseum.nl (30.08.2016).

'She's a hunter now', Women in the World in association with the New York Times, http://nytlive.nytimes.com/womenintheworld/2016/08/27/photos-of-8-year-old-girl-eating-the-heart-of-herfirst-kill-shock-users-on-facebook/ (29.08.2016). 